\title{
Short Interest and Market Risk Premium: The Case of the Korean Market
}

\author{
Do Kyol Lee, Assistant Manager, Shinan Life \\ Dohyun Chun ${ }^{*}$, Ph.D Candidate, KAIST \\ Hoon Cho, Professor, KAIST
}

\begin{abstract}
This study investigates the predictability of short interest over aggregate market risk premium. We construct an aggregate short interest index (SII) using firm-level short interest data, and use predictive regression analysis to compare the predictive power of SII and widely used macro variables. We find that the SII outperforms the macro variables under short-term forecasts and asset allocation. This supports our hypothesis that although short sellers are informed traders, they cannot eliminate the mispricing owing to arbitrage limit and low short selling volume. We demonstrate that the market predictability of SII mostly stems from the future cash flow channel.
\end{abstract}

Keywords: Short Interest Index; Market Risk Premium; Macro Variables; Predictive Regression; Informed Traders

JEL Classification: C22, C58, G14, G15

\footnotetext{
* Corresponding Author. Address: College of Business, Korea Advanced Institute of Science and Technology, Seoul, 85, Hoegi-ro, Dongdaemun-gu, Seoul, Korea 02455; E-mail: dohyun0323@kaist.ac.kr; Tel: +82-2-958-3482; Fax: +82-2-958-3620.
}

Received: December 10, 2018; Revised: March 29, 2019; Accepted: April 18, 2019 


\title{
공매도 지수를 이용한 시장 리스크 프리미엄 예측
}

\author{
이 도 결 (신한생명 전임) \\ 천 도 현 (KAIST 박사과정)* \\ 조훈 (KAIST 교수)
}

<요 약>

본 연구에서는 시장 리스크 프리미엄에 대한 공매도 정보의 예측력을 확인하기 위하여 공매도 지수 (Short Interest Index)를 구축하고 기존의 문헌에서 널리 사용되었던 거시경제 및 시장 변수들과 예측력을 비교 분석하였다. 실증분석 결과, 내표본과 외표본 모두에서 공매도 지수(SII)의 단기 예측력이 기존 예측 변수들보다 우수하며, 자산배분 측면에서도 좋은 성과를 보임을 확인했다. 이는 공매도 거래자가 정보거래자이며, 차익거래 제약과 상대적으로 낮은 공매도 거래량으로 인해 가격 괴리를 완전히 해소하지 못한다는 본 연구의 가설을 지지하는 결과이다. 나아가 공매도 정보의 미래 수익률 예측력이 대부분 미래 현금 흐름 예측에 기인함을 실증적으로 규명하였다. 종합하면, 공매도 거래자들은 미래 현금 흐름에 대한 예측력이 있는 정보거래자라고 결론 내릴 수 있다. 이는 Miller(1977)의 정보 거래가설을 지지하는 결과이다.

핵심 단어 : 공매도 지수, 시장 리스크 프리미엄, 거시경제변수, 예측회귀분석, 정보거래자

JEL 분류기호: C22, C58, G14, G15

* 연락담당 저자. 주소: 서울특별시 동대문구 회기로 85 한국과학기술원 SUPEX 경영관 S582, 02455; E-mail: dohyun0323@kaist.ac.kr; Tel: 02-958-3482; Fax: 02-958-3620. 


\section{1. 서론}

주식시장의 리스크 프리미엄은 포트폴리오 이론에서 재무관리에 이르는 재무의 근원적인 분야에 큰 영향을 미치며, 시장 리스크 프리미엄을 예측하기 위한 연구가 활발하게 진행되어 왔다 (Ang and Bekaert, 2006; Cochrane, 2008; Welch and Goyal, 2007; Campbell and Thompson, 2007; Rapach and Zhou, 2013; Neely et al., 2014; Pettenuzzo et al., 2014; Kelly and Jiang, 2014; McLean and Pontiff, 2016). 미래 시장에 대한 정보를 가지고 있는 정보거래자의 투자 행태는 수익률 예측에 대한 중요한 단서를 제공한다. Miller(1977)와 Diamond and Verrecchia(1987)의 연구에 따르면 시장에는 다양한 의견을 가진 투자자가 있고, 공매도 제약이 존재하는 경우 공매도 거래자는 대부분 정보거래자이다(정보거래가설, informed trading hypothesis). 물론 비정보거래자도 시장의 유동성 확보 차원에서 공매도 거래를 실시하지만, 정보거래자는 시장에 앞서 미래 주가 정보를 취득하여 주식을 대차하고 매도한다. 그리고 예상대로 주가가 하락하면 시장에서 주식을 매수, 대여자에게 상환하여 차익을 취한다. 투자자는 공매도 거래에서 발생하는 비용보다 기대되는 수익이 큰 경우에만 거래를 실시하므로 공매도 거래에는 유동성 거래를 위한 비정보거래자보다 정보거래자의 비중이 상대적으로 높을 것을 유추할 수 있다. 공매도 거래자가 미래 주가에 대한 정보를 가진 정보 거래자라면, 공매도 제약은 정보거래자의 시장 참여를 제한하여 해당 주가에 대한 과대평가를 초래한다. 이 경우 공매도 제약으로 과대평가된 주가가 조정되는 과정에서 주가 하락이 발생 하므로 공매도 거래와 미래 주가수익률은 음의 상관관계를 가진다.

Miller(1977)와 Diamond and Verrecchia(1987)의 연구 이후 공매도 거래와 미래 주가 수익률 간에 다양한 연구가 진행되었다. 실증분석을 통해 공매도 거래자가 정보거래자임을 밝힌 대표적인 연구들은 Christophe et al.(2004), Chang et al.(2007), Diether et al.(2008), Christophe et al.(2010), Karpoff and Lou(2010) 등이 있다. Christophe et al.(2004)은 나스닥(NASDAQ)에 상장된 개별 기업에 대해, 이익 발표 전의 공매도 거래량이 발표 후 주가 수익률과 음의 관계가 있음을 밝혔다. Chang et al.(2007)은 홍콩 주식시장에서 공매도 제약이 주가의 과대평가를 초래함을 실증적으로 보였다. Diether et al.(2008)은 미국증권위원회 (SEC)와 뉴욕증권거래소(NYSE)에서 발생한 공매도 거래 자료를 분석한 결과, 공매도 거래 증가가 단기 미래 주가 수익률에 부정적인 영향을 미침을 보였다. Christophe et al.(2010)은 미국 나스닥 기업의 애널리스트 투자의견과 공매도 거래의 수익성을 분석하여 투자 축소 의견 직전의 공매도 거래가 수익성이 있음을 보였다. 한국시장에서도 공매도 거래의 정보거래가설을 실증 분석하는 연구들이 진행되었다. $\operatorname{Kim}(2000)$ 는 공매도 거래 직후 주가 수익률에 대한 분석을 진행하여 한국 주식시장에서 공매도 거래가 정보 거래임을 실증적으로 보였다. Hwang and Cho(2011)와 Woo and Kim(2017)은 한국시장에서 공매도 거래와 미래 주가 수익률 간에 음의 상관관계가 있음을 보여 정보 거래 가설을 지지하였다. Wang and Lee(2015)는 외국인 투자자를 
중심으로 공매도 거래를 분석하여, 외국인의 대규모 공매도 거래가 미래 주가 수익률에 대한 단기 예측력이 있음을 밝혔다. 또한, Kim and Lee(2013)은 외국인 투자자의 공매도 정보를 활용한 투자전략의 성과를 분석하여 벤치마크 전략보다 보다 높은 성과를 획득함을 보였다. $\mathrm{Eom}(2012)$ 은 KOSDAQ시장에서 애널리스트의 투자의견과 공매도 간의 관계를 분석하여 Christophe et al.(2010)의 연구결과와 같이 애널리스트의 부정적 투자의견 직전의 공매도 거래가 수익성이 있음을 보였다.

한편, 다음 연구들은 공매도 거래가 정보거래라고 보기 어렵다고 주장하였다. Daske et al.(2005)은 기업의 경영성과 발표 전의 부정적인 뉴스와 공매도 거래 간의 관계를 분석하였다. 그 결과, 경영성과 발표 전 부정적인 뉴스와 공매도 거래 사이에 유의한 관계를 발견하지 못하였다. Henry and Koski(2010)는 유상증자 직전의 공매도 거래 자료를 활용하여 공매도 거래자를 분석하였으나, 공매도 거래와 해당 기업 정보 사이의 관계에 대한 유의한 증거를 발견하지 못했다. 이외에도 한국시장에서 공매도 거래가 정보 거래라고 보기 어렵다는 대표적인 연구들은 Song(2006), Yi et al.(2010), 그리고 Kim et al.(2011) 등이 있다. 그들은 공매도 거래와 미래 주가수익률 간에 유의한 음의 관계가 존재하지 않음을 실증적으로 밝혔다.

개별 주식에 대한 공매도 거래를 연구한 기존 연구들은 개별 기업의 공매도 변동성이 해당 기업의 미래 주가 수익률과 관련이 있음을 보였다(Senchack and Starks, 1993; Asquith et al., 2005; Desai et al., 2002; Diether et al., 2008). 하지만, 개별 기업에서의 관계가 반드시 시장 전반에 대해서도 동일하게 적용되지는 않는다는 사실은 널리 알려져 있다. 다음의 연구들은 개별 주식에서의 관계가 아닌 시장 전체의 공매도 정보와 시장 수익률 간의 관계를 살펴보고 있다. Seneca(1967)는 전월 중기에 본 시장 전체의 공매도와 S\&P 500 지수 사이에 유의한 음의 상관 관계가 존재함을 밝혔으나 현대 시계열분석과 계량경제학이 출현하기 전의 논문으로 직접적인 예측력을 살펴볼 수는 없었다는 한계가 있다. 이후 Lamont and Stein(2004)은 1995년에서 2002년까지의 나스닥 상장 기업들에 대한 공매도 자료를 분석하여 차익거래의 제한이 있을 때 공매도 거래자가 시장전체의 이론가와 시장가의 괴리를 해소하는데 어려움이 존재함을 규명 하였다. Lynch et al.(2014)은 NYSE, 나스닥을 포함한 다양한 미국 주식 시장을 대상으로 2005년 1월부터 2007년 7월까지의 일별 공매도 거래량을 조사하였다. 해당 연구에서는 공매도 투자자들이 시장 전반에 대한 정보를 가지고 있으며, 전체 공매도 거래량은 미래 시장 수익률을 예측할 수 있는 정보를 포함하고 있다고 주장하였다. 그리고 전체 공매도 거래량을 활용하여 미래 5일에서 20일까지의 시장 수익률에 대한 예측력을 증가시킬 수 있음을 보였다. Rapach et al.(2016)은 2014년 12월부터 2017년 1월까지 공매도 거래량을 이용하여 공매도 지수를 구축 하고 S\&P500 초과 수익률에 대한 예측력을 검정하였다. 해당 연구에서는 공매도 지수가 Welch and Goyal(2007)에서 사용한 14개의 예측변수에 비해 유의하게 높은 내표본 및 외표본 예측력을 가지며, 자산배분 측면에서의 성과도 우월함을 확인했다. 나아가 공매도 거래자들이 미래 시장 전반의 현금흐름에 대한 정보를 가지고 있는 정보거래자임을 확인하였다. 
한국증권학회지 제48권 5호 (2019)

본 연구에서는 한국 주식 시장 초과 수익률에 대한 공매도 지수의 예측력을 계량적으로 확인하기 위하여 다음과 같은 순서로 분석을 진행한다. 첫째, 한국 유가증권시장(KOSPI), $\mathrm{KOSDAQ}$ 시장을 포함한 금융 시장 전반의 공매도 거래량을 고려하여 한국의 시장 공매도 지수를 구축한다. 이 때 공매도 지수는 시장 전체의 공매도 거래에 관한 정보를 담고 있으며, 시장의 하방 리스크를 측정할 수 있을 것으로 기대된다. 둘째, 공매도 지수의 예측력을 검증 하기 위하여 시장 수익률 예측에 널리 사용되는 13 개의 거시경제 및 시장 변수를 구축한다. 셋째, 그레인져 인과관계 분석을 통해 시장 리스크 프리미엄과 공매도 지수(SII) 간의 선행성을 확인한다. 넷째, Welch and Goyal(2007)의 예측회귀분석 방법론을 바탕으로 내표본과 외표본 예측회귀분석을 진행하여 공매도 지수와 기존 거시경제 및 시장 변수들과 장단기 예측력을 통계적으로 비교한다. 다섯째, 시장 공매도 지수 예측력의 경제학적 의의를 분석하기 위하여 Campbell and Thomson(2007)의 방법론을 바탕으로 한 자산배분을 진행하여 공매도 지수의 자산배분 성과를 기존 거시경제 및 시장 변수들과 비교한다. 마지막으로, Campbell(1991), Campbell and Ammer(1993)의 벡터자기회귀(VAR) 방법론을 활용하여 공매도 지수의 시장 예측력에 대한 핵심 동인(動因)을 분석한다. 이를 통해 공매도 지수의 예측력이 미래 현금 흐름 정보와 할인율 정보 중 어떤 정보 기인한 것인지 확인할 수 있다.

본 연구는 시계열분석과 계량경제학적 기법을 이용하여 전체 공매도 정보가 단기 리스크 프리미엄에 대한 좋은 예측력을 가진다는 것을 보였다는데 의의가 있다. 분석 결과 내표본과 외표본 모두에서 공매도 지수(SII)의 단기 예측 성과가 기존 거시경제 및 시장 변수들보다 통계적으로 우수하며, 자산배분 측면의 성과도 우월함을 확인했다. 또한 기존의 예측 변수들을 시장 정보에 대한 추정치로 본다면 VAR 분석 결과는 공매도 거래자가 경제 내의 미래 현금 흐름에 대한 사전 정보를 획득하고 이를 이용하여 이익을 취한다는 것을 의미한다. 이러한 발견은 공매도 거래자가 기업 고유의 정보를 이용하여 초과 수익을 얻는다는 기존 연구 결과들과 일치하는 결과이다(Akbas et al., 2013; Boehmer et al., 2008; Engelberg et al., 2012; Karpoff and Lou, 2010). 그리고 정보거래자인 공매도 거래자가 시장 전체 현금 흐름에 대한 예측을 통하여 시장 전체의 미래 움직임을 예측하므로, 공매도 거래에 담긴 정보가 경제 전반의 측면에서도 중요한 요소임을 증명했다고 볼 수 있다. 종합하면 공매도 거래자들은 대부분 미래 주가 수익률에 큰 영향을 미치는 현금 흐름에 대한 예측력이 있는 정보거래자라고 결론 내릴 수 있으며, 이는 Miller(1977)의 정보거래가설을 지지한다.

본 연구의 구성은 다음과 같다. 제 2장에서는 연구에 활용되는 분석자료를 소개하고 이를 토대로 본 연구의 핵심 변수인 공매도 지수(SII)와 기존 거시경제 및 시장 변수들을 도출한다. 제 3장에서는 예측회귀분석, 자산배분분석, VAR 등의 방법론을 설명한다. 제 4장에서는 분석 결과를 확인하고 해석한다. 마지막으로 제 5 장에서는 본 연구의 결론을 제시하고 한국 시장 에서 공매도의 경제적 의미와 그 시사점에 대해 논한다. 


\section{2. 공매도 지수와 예측 변수}

\section{1 공매도 지수}

본 장에서는 Miller(1977)와 Diamond and Verrecchia(1987)의 정보 거래 가설에 근거 하여, 한국시장의 개별기업의 공매도 잔고를 활용한 시장 공매도 지수를 구축한다. 2008년 이후 한국거래소에서는 매월 개별기업의 공매도 잔고 자료를 공개하고 있으며, 본 연구에서는 DataGuide에서 제공하는 2008년 6월부터 2016년 8월까지의 월별 공매도 자료를 이용하였다. 분석 대상에는 KOSPI 및 KOSDAQ 상장기업, ETFs(Exchange trading funds), 리츠(Real Estate Investment Trusts, REITs)를 포함하였고, 분석 기간은 2008년 6월부터 2017년 8월까지이다. 시장 공매도 지수는 다음과 같이 구할 수 있다.

$$
\text { 시장 공매도 지수 }=\log \left[\frac{1}{\sum_{i} V_{i}}\left(\sum_{i} V_{i} \times \frac{S_{i}}{N_{i}}\right)\right]
$$

여기서 $V_{i}$ 는 개별기업의 시가총액, $S_{i}$ 는 개별기업의 공매도 잔고, $N_{i}$ 는 개별기업의 발행 주식수를 의미한다. 시장 공매도 지수는 한국시장에 상장되어 있는 전체 기업의 공매도 거래 비중(공매도 잔고/발행주식수)에 대한 시가총액기준 가중평균을 로그 변환하여 구성 하였다. 따라서 공매도 지수는 주식시장뿐만 아니라 $\mathrm{ETF}$, 리츠 등 다양한 금융시장의 공매도 정보를 담고 있다. 과거에는 한국시장에서 주식 대비 $\mathrm{ETF}$ 나 리츠의 시장규모가 작아 분석 대상에 포함하지 않는 경우가 많았으나 최근 대체 자산의 수요와 상승세를 고려하여 분석 대상에 포함하였다. 특히, 한국 $\mathrm{ETF}$ 시장의 순자산총액은 세계 10 위 수준이며, 일평균거래 대금은 세계 5위이다. ${ }^{1)}$ 또한, ETF 시장은 15 년간 순자산 규모가 89배 성장하였으며, 개인 투자자보다 기관투자자의 비중이 높다. 이러한 측면을 고려하였을 때, ETF 시장은 정보거래자의 비중이 상대적으로 높을 것으로 판단된다.

<그림 1>은 2008년 6월에서 2017년 8월까지의 시장 공매도 지수이며, 한국 시장 전반의 공매도 거래 추이를 나타낸다. 한국시장의 경우, 과거 2 차례의 공매도 금지기간이 있었다. 첫째, 2008년 금융위기 국면에 공매도 지수가 급등하다 하락하는 것을 확인할 수 있는데, 글로벌 금융위기 동안 금융위원회가 2008년 10월에서 2009년 5월까지 공매도를 금지 하였기 때문이다. ${ }^{2}$ 둘째, 2011년 6월 국면에서도 공매도 지수가 증가하다 가파르게 하락 하는 것을 확인할 수 있다. 이는 2011년 8월 유로존 재정위기 확산, 미국의 경기둔화 및 신용등급 하락 등으로 국내 KOSPI 지수가 급격히 하락했기 때문으로 금융위원회는 2011년 8월에서 2011년 11월까지 3개월간 KOSPI 및 KOSDAQ시장에 대해 공매도를 전면 금지

1) 2017년 8월 기준(출처: ETFGI LLP).

2) 공매도 거래량이 0이 아닌 이유는 유동성공급자(LP), 거래소 상장 $\mathrm{ETF}, \mathrm{ELW}$ 및 장외파생상품 헤지를 위한 차입공매도는 예외적으로 허용하였기 때문이다. 
한국증권학회지 제48권 5호 (2019)

하였다. 따라서, 한국시장의 경우 2008년 10월부터 8개월간, 2011년 8월부터 3개월간 공매도가 전면 금지되어 공매도 지수가 0에 가깝다.

〈그림 1〉한국시장의 시장 공매도 지수

그림은 본 연구에서 구축한 월별 시장 공매도 지수를 나타낸다. 시장 공매도 지수는 KOSPI 및 $\mathrm{KOSDAQ}$ 상장기업, ETFs, REITs 등을 고려하여 계산되었다. 분석 기간은 2008년 6월부터 2017년 8월까지이다.

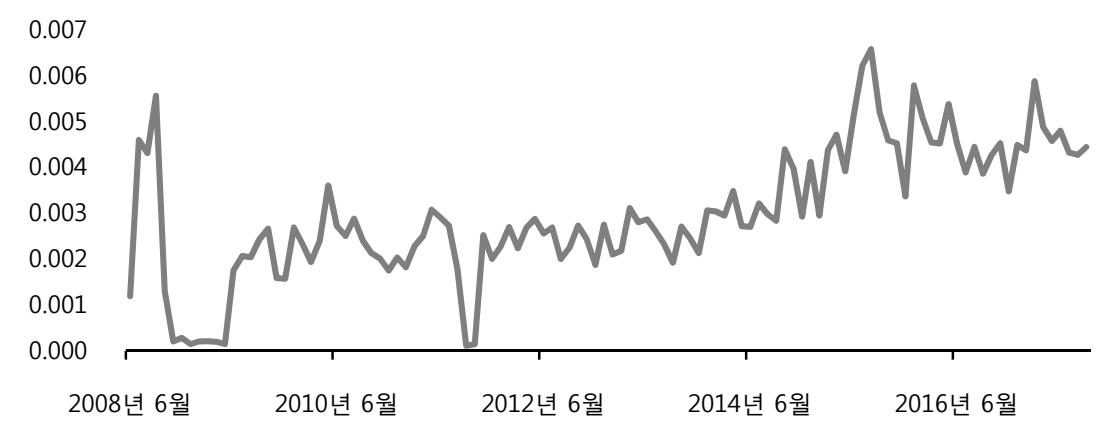

<그림 1 >에서 시간에 따른 공매도 지수의 선형 추세를 확인할 수 있는데, 이러한 시간 추세가 공매도 정보를 왜곡할 수 있음이 알려져 있다. ${ }^{3)}$ 한국 시장에서 공매도 지수가 선형 추세를 갖는 이유는 크게 두 가지이다. 첫째, 자본시장의 규모가 전세계적으로 커짐에 따라, 증권대차시장이 발전하였기 때문이다. 증권대차시장의 발전은 공매도 거래비용을 낮추는 역할을 하여, 공매도 지수가 시간이 지남에 따라 증가한 것으로 해석할 수 있다. 둘째, 선진 금융거래 기법의 발전에 따라 공매도 거래에 대한 수요가 증가하였기 때문이다. 예를 들면, 레버리지와 롱-숏(long-short) 전략을 과감히 구사하는 헤지펀드의 증가로 시간이 지남에 따라 공매도 지수가 증가한 것으로 해석할 수 있다. 따라서, 본 연구에서는 식 (2)의 모형을 통해 시간에 따른 선형 추세가 존재하는지 통계적으로 검정하였다. 여기서 $R S I I$ 는 선형 추세가 제거되지 않은 시장 공매도 지수를 의미한다.

$$
R S I I_{t}=a+b \cdot t+u_{t} \text { for } t=1, \ldots, T
$$

본 연구에서는 최소자승법(OLS)으로 식 (2)를 추정한 후 시간 추세를 제거한 잔차 $\left(\hat{u}_{t}\right)$ 를 구하고 이를 표준편차로 나누어 표준화하였다. 결과적으로 표준화된 $\hat{u}_{t}$ 를 본 연구에서 사용할 최종적인 공매도 지수(SII)로 정의하였다. 선형 추세가 제거된 공매도 지수는 공매도 거래의 변화량을 측정하며, 단순한 공매도 조건 완화나 차익거래에 의한 거래 추이 변화가 아닌 공매도 거래자의 예측 변화를 반영할 수 있다. <그림 2>는 시간 추세를 제거한 공매도 지수와 다음 달 KOSPI 지수의 초과수익률을 함께 나타낸 그림이다. 공매도 지수(SII)와 미래 시장

3) Rapach et al.(2016) 등에 따르면, 미국시장의 경우에서도 공매도 거래량에 시간 추세가 존재하며, 통계적으로 유의한 선형, 2차(quadratic), 3차(cubic), 확률적(stochastic) 추세가 존재한다. 
리스크 프리미엄간의 관계를 살펴보면 전반적으로 음의 관계를 가지는 것을 볼 수 있다. 특히, 2008년 글로벌 금융위기나 2015년 중국의 증시폭락 등 하락국면에서 공매도 지수 (SII)가 크게 상승하며, 다음 달 주식시장의 리스크 프리미엄이 하락하는 것을 볼 수 있다. 따라서 공매도 거래량은 미래 시장 리스크 프리미엄에 대한 예측력을 가지며, 음의 상관 관계를 가질 것으로 예상된다.

〈그림 2〉시간 추세를 제거한 공매도 지수(SII)와 KOSPI 지수 초과수익률 그림은 시간 추세를 제거한 공매도 지수(SII)와 1 개월 선행 KOSPI 지수의 초과수익률을 나타낸다. 분석 기간은 2008년 6월부터 2017년 8월까지이다. 비교를 위하여 두 변수는 표준편차로 나누어 표준화하였다.

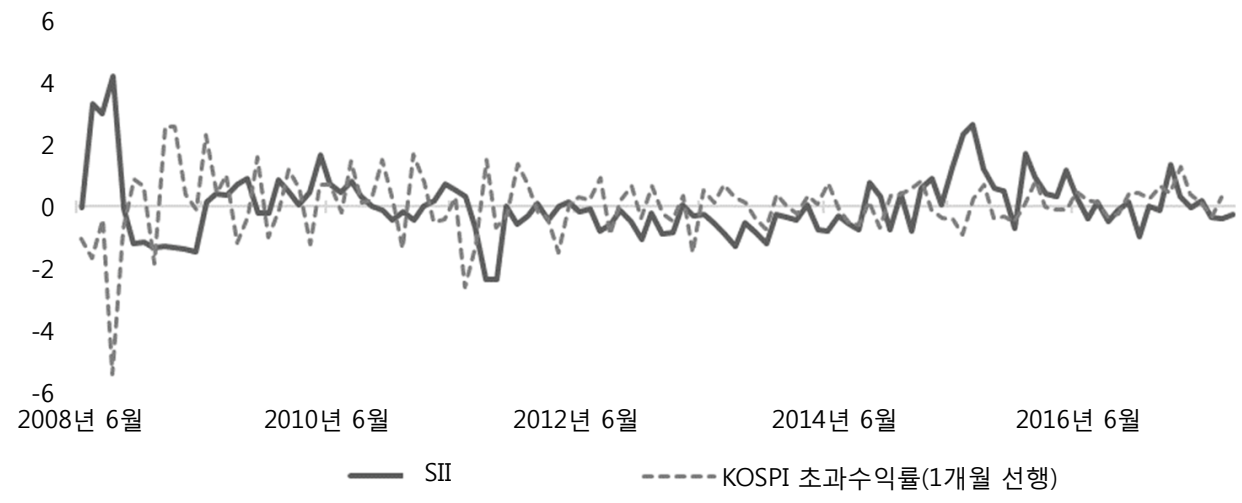

\section{2 거시경제 및 시장 변수}

본 장에서는 연구에서 사용한 13 가지 거시경제 및 시장 변수들을 소개한다. 해당 변수 들은 Welch and Goyal(2007)을 비롯한 여러 시장수익률 예측 문헌에서 통상적으로 활용 되는 변수들이며, 공매도 지수(SII)의 예측력과 기존 연구결과를 비교하기 위한 벤치마크로 사용된다. 주식시장의 개별 기업에 관한 정보는 DataGuide, 금리 정보와 소비자 물가지수는 통계청에서 제공받았다. 각 변수에 관한 구체적인 도출 방법은 아래와 같다.

1) 로그 배당-주가 비율 $(\log$ dividend-price ratio, $D P)$ : KOSPI 지수의 배당에 대한 12 개월 이동합(moving sum)을 현재 시점의 KOSPI 지수로 나눈 후 로그 변환. KOSPI 지수 배당은 해당 지수에 속한 개별 기업의 배당을 시가총액으로 가중평균하여 도출함.

2) 로그 배당 이익률 (log dividend yield, DY): KOSPI 지수의 배당에 대한 12개월 이동합을 이전 시점 KOSPI 지수로 나눈 후 로그 변환함.

3) 로그 이익-가격 비율 (log earnings-price ratio, EP): KOSPI 지수의 이익(earnings)에 대한 12 개월 이동합을 현재 시점의 KOSPI 지수로 나눈 후 로그 변환. KOSPI 지수의 이익은 해당 지수에 속한 개별 기업의 이익을 시가총액으로 가중평균하여 도출함.

4) 로그 배당성향 $(\log$ dividend-payout ratio, $D E)$ : KOSPI 지수의 배당에 대한 12 개월 이동합을 KOSPI 지수의 이익에 대한 12 개월 이동합으로 나눈 후 로그 변환함. 
5) 초과 주가 수익 변동성(Excess stock return volatility, RVOL): 초과 주가 수익의 12 개월 이동 표준편차(Mele, 2007).

6) 장부가-시가 비율(Book-to-market ratio, $B M)$ : KOSPI 지수에 속한 개별 기업의 장부가-시가 비율을 시가총액으로 가중평균.

7) 순자산확대(Net equity expansion, NTIS): 순자산확대는 KOSPI상장 기업들의 순자산 증가량을 측정하는 변수로써, $\mathrm{KOSPI}$ 지수에 상장된 주식들의 상장 주식수 순 증가량의 12 개월 이동합을 연말 KOSPI 지수의 전체 시가총액으로 나누어 구함.

8) 국채 이자율(Treasury bill rate, $T B L)$ : 1 년 국고채 이자율.

9) 장기 이자율(Long-term yield, $L T Y$ ): 10 년 국고채 이자율.

10) 금리스프레드(Term spread, TMS): 10 년 국고채와 1 년 국고채 간의 이자율 차이.

11) 부도 금리 스프레드(Default yield spread, $D F Y$ ): $\mathrm{BBB}$ - 등급과 $\mathrm{AA}-$ 등급 회사채 간 이자율 차이.

12) 인플레이션(Inflation, INFL): 소비자 물가 지수(Consumer Price Index)의 변화율.

예측 변수들과 공매도 지수 간의 관계를 파악하기 위해 요약 통계량과 변수간 상관관계를 구하였다. <표 1>의 패널 A에는 각 변수에 대한 평균, 중앙값, 표준편차, 99 퍼센타일(99th percentile)과 1 퍼센타일(1st percentile)이 제시되어 있다. <표 1> 패널 $\mathrm{A}$ 의 마지막 행과 패널 $\mathrm{B}$ 를 보면 공매도 지수(SII)의 평균값은 0.0030, 중앙값은 0.0027, 99 퍼센타일 값은 0.0062 이고 시간에 따라 평균값이 점점 증가하는 것을 알 수 있다.

〈표 1〉공매도 지수(SII)와 한국 시장의 거시경제 및 시장 변수의 요약 통계량 및 시간에 따른 공매도 지수(SII)의 평균 변화

표의 패널 $\mathrm{A}$ 는 공매도 지수(SII)와 한국 시장의 거시경제 및 시장 변수 자료의 평균, 중앙값, 상위 $1 \%$ 와 하위 $1 \%$ 값 그리고 표준편차를 나타낸다. 패널 $\mathrm{B}$ 는 시간에 따른 공매도 지수(SII)의 평균의 변화를 나타낸다. 패널 $\mathrm{A}$ : 요약 통계량

\begin{tabular}{lrrrrc}
\hline \multicolumn{1}{c}{ 변수 } & 평균 & 중앙값 & 1st percentile & 99th percentile & 표준편차 \\
\hline$S I I$ & 0.003 & 0.003 & 0.000 & 0.006 & 0.001 \\
$D P$ & -4.321 & -4.365 & -4.630 & -3.751 & 0.199 \\
$D Y$ & -4.318 & -4.362 & -4.636 & -3.792 & 0.192 \\
$E P$ & 0.210 & 0.208 & -0.008 & 0.473 & 0.123 \\
$D E$ & -7.007 & -6.998 & -7.339 & -6.621 & 0.202 \\
$R V O L$ & 0.042 & 0.033 & 0.015 & 0.101 & 0.023 \\
$N T I S$ & 0.004 & 0.004 & 0.001 & 0.010 & 0.002 \\
$T B L$ & 0.002 & 0.002 & 0.001 & 0.005 & 0.001 \\
$L T Y$ & 0.003 & 0.003 & 0.001 & 0.005 & 0.001 \\
$T M S$ & 0.001 & 0.001 & 0.000 & 0.002 & 0.001 \\
$D F Y$ & 0.005 & 0.005 & 0.002 & 0.005 & 0.001 \\
$I N F L$ & 0.002 & 0.001 & -0.005 & 0.012 & 0.003 \\
$B M$ & 1.008 & 1.003 & 0.811 & 1.432 & 0.103 \\
\hline
\end{tabular}


〈표 1〉 공매도 지수(SII)와 한국시장의 거시경제 및 시장 변수의 요약 통계량 및 시간에 따른 공매도 지수(SII)의 평균 변화(계속)

패널 B: 시간에 따른 공매도 지수(SII)의 평균

\begin{tabular}{ccccc}
\hline & 2008. 06 & 2011.01 & 2013.07 & 2016. 01 \\
& 2010.12 & 2013.06 & 2015.12 & 2017.08 \\
\hline SII & 0.0020 & 0.0023 & 0.0036 & 0.0046 \\
\hline
\end{tabular}

다음으로 <표 2>에는 변수간 상관관계 도표가 제시되어 있으며 기존 거시경제 및 시장 변수간의 상관관계가 전반적으로 높은 것을 확인할 수 있다. 특히 $D P$ 와 $D Y$ 가 0.97로 높은 양의 상관관계를 보이고 $E P$ 와 $D E$ 가 -0.56 로 높은 음의 상관관계를 보이는데 이런 경우 해당 변수들을 독립 변수로 하여 다중회귀분석 할 경우 변수간 다중 공선성 문제가 발생할 위험이 있다. 반면, 공매도 지수는 전반적으로 기존 변수들과의 상관관계가 낮다. 절대값을 기준으로 공매도 지수와 상관관계가 가장 높은 변수는 NTIS이며(0.46), 가장 낮은 변수는 $I N F L$ 이다(-0.02). 즉 공매도 지수(SII)는 기존 거시경제 및 시장 변수와 다른 특별한 정보를 가지고 있을 가능성이 있다.

〈표 2〉각 예측변수간의 상관관계

\begin{tabular}{lrrrrrrrrrrrrr}
\hline & $S I I$ & $D P$ & $D Y$ & $E P$ & $D E$ & RVOL & NTIS & TBL & LTY & TMS & DFY & INFL & BM \\
\hline SII & 1 & & & & & & & & & & & & \\
$D P$ & 0.19 & 1 & & & & & & & & & & & \\
$D Y$ & 0.15 & 0.97 & 1 & & & & & & & & & & \\
$E P$ & 0.03 & 0.17 & 0.14 & 1 & & & & & & & & & \\
$D E$ & 0.30 & 0.50 & 0.52 & -0.56 & 1 & & & & & & & & \\
RVOL & -0.06 & 0.15 & 0.15 & 0.23 & -0.31 & 1 & & & & & & & \\
NTIS & 0.46 & 0.61 & 0.56 & 0.38 & 0.21 & 0.19 & 1 & & & & & & \\
TBL & 0.10 & 0.01 & -0.07 & 0.27 & -0.41 & 0.66 & 0.43 & 1 & & & & & \\
LTY & 0.06 & -0.07 & -0.10 & 0.25 & -0.40 & 0.84 & 0.30 & 0.85 & 1 & & & & \\
$T M S$ & -0.02 & -0.14 & -0.09 & 0.09 & -0.16 & 0.62 & -0.06 & 0.15 & 0.65 & 1 & & & \\
$D F Y$ & -0.23 & -0.42 & -0.33 & 0.07 & -0.08 & -0.31 & -0.61 & -0.70 & -0.42 & 0.21 & 1 & & \\
$I N F L$ & -0.02 & -0.04 & -0.02 & 0.15 & -0.08 & 0.12 & 0.13 & 0.08 & 0.18 & 0.22 & 0.04 & 1 & \\
BM & -0.11 & 0.60 & 0.52 & -0.05 & 0.27 & -0.06 & 0.02 & -0.29 & -0.27 & -0.08 & -0.14 & -0.14 & 1 \\
\hline
\end{tabular}

\section{3. 분석 방법론}

\section{1 예측회귀분석}

\subsection{1 내표본 분석}

공매도 지수(SII)와 미래 주가수익률 간의 관계를 통계적으로 검증하기 위하여 본 연구 에서는 다음 예측회귀분석 모형을 사용하였다.

$$
r_{t: t+h}=\alpha+\beta x_{t}+\varepsilon_{t: t+h}
$$


한국증권학회지 제 48 권 5호 (2019)

$$
r_{t+1}=\log \left[\frac{\left(P_{t+1}+D_{t+1}\right)}{P_{t}}\right]-\log \left(1+r_{t+1}^{f}\right)
$$

여기서 $r_{t: t h}$ 는 $t$ 시점부터 $t+h$ 시점까지의 KOSPI 초과수익률 평균, $x_{t}$ 는 예측 변수를 의미한다. $r_{t+1}^{f}$ 는 무위험 이자율을 의미하며, 본 연구에서는 91 일 $\mathrm{CD}$ 금리를 사용하였다.

본 연구에서는 리스크 프리미엄에 대한 예측력을 비교하기 위하여 Welch and Goyal (2007)의 거시경제 및 시장 변수들과 공매도 지수(SII)를 설명 변수로 하여 단변량 예측 회귀분석을 진행하였다. 분석 기간은 2008년 6월부터 2017년 8월까지이고, 월별 $(h=1)$, 분기별 $(h=3)$, 반기별 $(h=6), 9$ 개월별 $(h=9)$, 연별 $(h=12)$ 로 나누어 각 예측변수의 $\beta$ 를 추정하였다. 예측변수들의 표준편차를 1 로 통일하기 위해, 각 예측변수의 표준편차로 나누어 표준화하였다.

단변량 회귀모형에서 종속변수를 설명하는데 필요한 변수를 포함하지 않은 경우 다른 설명 변수의 계수가 과대 혹은 과소 추정될 위험(누락 변수 편의, Omitted variable bias)이 있다. 이와 같은 문제를 통제하고자 다음과 같은 회귀모형을 세워 예측 회귀분석을 실시하였다.

$$
r_{t: t+h}=\alpha+\beta_{S I I} S I I_{t}+\sum_{i=1}^{3} \beta_{f, i} P C_{i, t}+\varepsilon_{t: t+h}
$$

여기서 $P C_{1, t}, P C_{2, t}, P C_{3, t}$ 는 각각 주성분 분석을 통하여 구한 첫 번째, 두 번째, 세 번째 성분이다 (Welch and Goyal, 2007). Ludvigson and $\mathrm{Ng}$ (2007)의 연구결과에 따르면, 주성분 분석은 설명 변수가 많은 예측 회귀분석을 실시할 때 효과적인 차원 축소방법론이다.

마지막으로, 거시경제 및 시장 변수 외의 기업특성 및 시장 요인을 포함하여 공매도 지수 (SII)의 예측력을 검증하였다. Fama and French(1992), Carhart(1997)의 방법론에 따라 시장 $(M K T)$, 기업규모 $(S M B)$, 가치 $(H M L)$, 모멘텀(MOM) 요인을 포함한 식 (6)의 회귀모형을 분석하였다.

$$
r_{t: t+h}=\alpha+\beta_{S I I} S I I_{t}+\beta_{M K T} M K T_{t}+\beta_{S M B} S M B_{t}+\beta_{H M L} H M L_{t}+\beta_{M O M} M O M_{t}+\varepsilon_{t: t h}
$$

\section{1 .2 외표본 분석}

본 장에서는 공매도 지수(SII)와 거시경제 및 시장 변수의 예측력을 비교하기 위한 외표본 분석 방법론을 소개한다. 공매도 지수(SII)나 거시경제 및 시장 변수가 리스크 프리미엄에 대해 유의한 예측력을 갖는다면, 적어도 예측변수의 정보를 전혀 활용하지 않는 과거평균 모형보다 예측력이 높을 것이다. 그러나, Welch and Goyal(2007)은 내표본에서 유의한 예측력을 갖는 변수일지라도 외표본에서 과거평균모형보다 예측력이 떨어질 수 있음을 실증적으로 보였다. 외표본 분석은 Welch and Goyal(2007)이 제시한 방법을 따라 진행하였다. 구체적인 분석 방법론은 다음과 같다. 


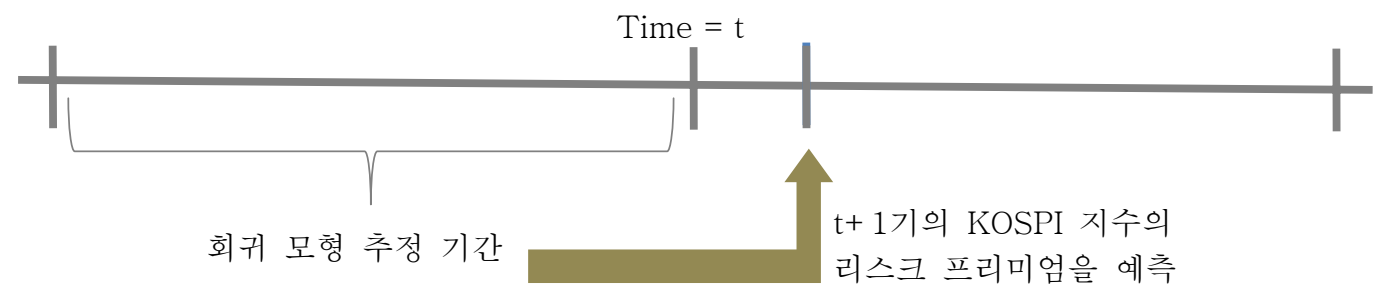

1) $t$ 시점 예측 변수로 다음의 두 예측 회귀 모형을 추정한다. 단, $\widehat{H M}_{t}$ 는 과거 평균 수익률을 의미한다.

$$
\begin{aligned}
& \text { Model A : } r_{t: t+h}=\hat{\alpha}_{t}+\hat{\beta}_{t} x_{t}+\varepsilon_{t: t+h} \\
& \text { Null Model }: r_{t: t+h}=\widehat{H M}_{t}+\varepsilon_{t: t+h}
\end{aligned}
$$

여기서 식 (7)은 예측 변수를 활용한 회귀 모형이고 식 (8)의 Null Model은 Model A에서 기울기가 0 인 모형으로, 예측 변수의 정보를 전혀 사용하지 않은 회귀 모형(과거평균모형)을 의미한다.

2) 위 모형에서 추정된 $\widehat{\alpha}_{t}, \widehat{\beta}_{t}, \widehat{H M}$ 를 활용하여 다음과 같이 $t+h$ 시점의 리스크 프리미엄을 예측한다.

$$
\begin{aligned}
& \text { Forecast } A: \widehat{r_{t+\mathrm{h}}^{A}}=\widehat{\alpha}_{j}+\widehat{\beta}_{j} x_{t} \\
& \text { Null Forecast }: \widehat{r_{t+\mathrm{h}}^{\text {Null }}}=\widehat{H M_{t}}
\end{aligned}
$$

3) 과정 1) 2)를 $T-h$ 번 반복하여 리스크 프리미엄에 대한 예측 시계열 $\widehat{r_{t+1}^{A}}, \widehat{r_{t+1}^{\text {Null }}}$, (단, $t=1, \ldots, T-h$ )을 구한다. 단, 매 추정과정에서 추정 시작 시점을 1 로 고정한 누적 표본을 이용한다.

4) 미래 리스크 프리미엄에 대한 두 예측 시계열 $\left(\widehat{r_{t+1}^{A}}, \widehat{r_{t+1}^{\text {Null }}}\right)$ 과 실제 시계열 $\left(r_{t+1}\right)$ 을 비교하여 평균 제곱 예측오차(mean squared forecast error, MSFE)를 구한다. 단, $M_{S F E}$ 와 $M S F E_{\text {Null }}$ 는 각각 예측 모형 $\mathrm{A}$ 와 Null 모형 하에서 구한 수익률 추정치의 평균 제곱 오차이다

$$
\begin{aligned}
\operatorname{MSFE}_{A} & =\frac{\sum\left(r_{t+1}-\widehat{r_{t+1}^{A}}\right)^{2}}{n} \\
\operatorname{MSFE}_{\text {Null }} & =\frac{\sum\left(r_{t+1}-\widehat{r_{t+1} \text { Null }}\right)^{2}}{n}
\end{aligned}
$$


5) Campbell and Thompson(2007)의 방법에 따라 외표본 $R_{O S}^{2}$ 통계량을 구한다.

$$
R_{O S}^{2}=1-\frac{M S F E_{A}}{M S F E_{\text {Null }}}
$$

만약 $R_{O S}^{2}$ 값이 0 보다 크다면 예측회귀모형의 평균 제곱 예측 오차가 과거평균모형보다 작다는 것을 의미하여 상대적으로 예측변수회귀 모형의 리스크 프리미엄에 대한 예측력이 뛰어난 것으로 해석할 수 있다.

6) $R_{O S}^{2}$ 의 통계적 유의성을 검증하기 위하여, $\mathrm{McCracken}(2007)$ 이 고안한 $F$-통계량을 사용한다.

$$
F_{M S F E}=(T-h+1) \times\left(\frac{M S F E_{\text {mull }}-M S F E_{A}}{M S F E_{A}}\right)
$$

여기서 $T$ 는 관측치의 수, $h$ 는 예측 기간을 나타낸다. 해당 검정의 귀무가설은 예측회귀 모형의 예측력이 과거평균모형보다 낮거나 같다 $\left(H_{0}: R_{O S}^{2} \leq 0\right)$ 는 것이고 대립가설은 예측회귀 모형의 예측력이 과거평균모형보다 높다 $\left(H_{A}: R_{O S}^{2}>0\right)$ 는 것이다.

\section{2 자산배분 분석}

본 장에서는 자산배분의 측면에서 공매도 지수(SII)의 경제적 가치를 평가하기 위해 Campbell and Thompson(2007)의 절차에 따라 위험자산과 무위험자산을 배분하는 평균분산 투자자를 고려하였다. 자산배분 평가 방법론은 다음과 같다.

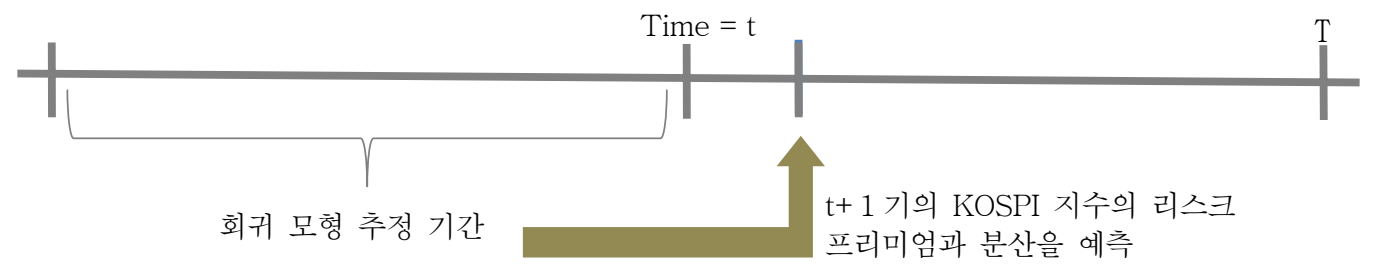

1) $t$ 시점 예측 변수를 활용하여 다음의 예측 회귀 모형을 추정한다:

$$
r_{t: t+h}=\hat{\alpha}_{t}+\hat{\beta}_{t} x_{t}+\varepsilon_{t: t h}
$$

2) 위 모형에서 추정된 $\hat{\alpha}_{t}, \hat{\beta}_{t}$ 를 활용하여 $t+1$ 시점의 리스크 프리미엄과 분산을 예측한다. $t+1$ 시점 예측 수익률 $\widehat{r_{t+1}}=\hat{\alpha}_{t}+\hat{\beta}_{t} x_{t}$ $t+1$ 시점 예측 분산 $\widehat{\sigma_{t+1}^{2}}$ : 과거 $t$ 시점까지의 리스크 프리미엄의 분산

3) 추정된 KOSPI 지수의 예측 리스크 프리미엄과 예측 분산을 고려할 때 $t+1$ 시점의 평균-분산 투자자가 보유할 최적 포트폴리오는 다음과 같다. 


$$
w_{t+1}=\frac{1}{\gamma} \times \frac{\widehat{r_{t+1}}}{\widehat{\sigma_{t+1}^{2}}}
$$

여기서 $\gamma$ 는 투자자의 위험회피계수로 본 연구에서는 기존 연구들과 같이 투자자의 위험 회피계수를 3 으로 정의하였다. 또한 국내 공모펀드의 레버리지 제약을 고려하여 포트폴리오의 범위를 $-0.3 \sim 1.3$ 사이로 설정하였다.

4) $t+1$ 시점에 투자자가 실제 실현한 수익률을 구한다.

5) 과정 1) 4)를 $t=T-h$ 까지 반복하여, 투자자가 실제 실현한 수익률과 분산을 구한다.

6) 자산배분의 성과평가는 샤프 비율(Sharpe ratio)과 확실성 등가 수익률(Certainty equivalent return, CER)을 활용한다.

$$
\begin{gathered}
\mathrm{CER}=E\left[r_{p}\right]-0.5 \gamma \sigma_{p} \\
\text { Sharpe ratio }=\frac{E\left[r_{p}\right]-r_{f}}{\sigma_{p}}
\end{gathered}
$$

여기서 $\mathrm{E}\left[R_{p}\right]$ 는 평가하고자 하는 임의의 포트폴리오의 기대수익률, $r_{f}$ 는 무위험수익률, 그리고 $\sigma_{p}$ 는 포트폴리오의 표준편차를 나타낸다. 확실성 등가 수익률은 위험 포트폴리오를 보유하는 대신, 투자자가 기꺼이 받아들일 수 있는 무위험 수익률이다.

본 연구에서는 투자성과평가를 위해 과거평균모형( $\beta=0$ 인 예측회귀모형)으로 추정한 리스크 프리미엄 $\left(\widehat{r_{t+1}}\right)$ 을 추정하고, 이를 이용한 포트폴리오를 벤치마크로 활용하였다. 확실성 등가 수익률 이익(CER gain)을 예측회귀모형을 활용한 포트폴리오의 확실성 등가 수익률과 과거 평균 모형을 활용한 포트폴리오의 확실성 등가 수익률의 차이로 정의하면, 확실성 등가 수익률 이익은 과거평균모형 대신 예측회귀모형을 사용하는데 투자자가 기꺼이 지불할 포트폴리오 운용비로 해석할 수 있다. 이를 활용하여 포트폴리오의 성과를 평가하고 시장 리스크 프리미엄에 대한 예측력의 경제적 가치를 측정하였다.

또한 장기 예측력의 경제적 가치를 평가하기 위해 리밸런싱 기간을 월별, 분기별, 반기별, 9 개월별, 연별로 나누어 분석하였다. 예를 들어, 분기별 리벨런싱 $(h=3)$ 의 경우, 투자자는 분기말에 리스크 프리미엄에 대한 예측회귀모형을 활용하여 다음 분기에 투자할 위험자산과 무위험자산의 비중을 업데이트한다. 마찬가지로 투자자는 각 리벨런싱 기간에 맞추어 포트폴리오의 비중을 업데이트한다.

\section{4. 결과 분석}

\section{1 그레인져 인과관계 분석}

<표 3>은 공매도 지수(SII)와 KOSPI 지수 수익률 간의 그레인져 인과관계를 분석한 결과이다. <표 3>의 첫 번째 열의 귀무가설은 공매도 지수(SII)가 KOSPI 지수 수익률을 선행하지 
한국증권학회지 제48권 5호 (2019)

않는다는 것이며, 대립가설은 공매도 지수(SII)가 KOSPI 지수 수익률을 선행한다는 것이다. 분석 결과, 시차가 1 개월, 2 개월, 3 개월, 4 개월인 경우 유의하게 귀무가설을 기각하여 공매도 지수가 KOSPI 지수 수익률을 선행하지만 시차가 5개월을 넘어갈 경우 귀무가설을 기각할 수 없었다. 즉, 공매도 지수 (SII)의 KOSPI 지수 수익률 대한 선행성은 4개월 정도 유지 된다. 이는 공매도 거래자들이 비교적으로 짧은 기간의 정보를 이용하여 공매도 거래를 하기 때문이며, 공매도 지수(SII)가 단기 예측에 강점을 보일 것이라고 예상할 수 있다.

〈표 3〉그랜저 인과관계 분석결과

각각의 귀무가설을 검정하기 위하여 공매도 지수(SII)와 KOSPI 지수 초과 수익률 사용

\begin{tabular}{|c|c|c|}
\hline$H_{0}$ & SII가 KOSPI를 선행하지 않는다 & KOSPI가 SII를 선행하지 않는다 \\
\hline 1 & $12.47(0.00)$ & $0.49(0.49)$ \\
\hline 2 & $6.53(0.00)$ & $1.92(0.15)$ \\
\hline 3 & $4.79(0.00)$ & $1.88(0.14)$ \\
\hline 4 & $4.66(0.00)$ & $4.07(0.00)$ \\
\hline 5 & $0.68(0.64)$ & 2.04(0.08) \\
\hline 6 & $1.50(0.19)$ & $1.62(0.15)$ \\
\hline 7 & $1.32(0.25)$ & $1.19(0.32)$ \\
\hline 8 & $1.92(0.07)$ & $1.14(0.34)$ \\
\hline 9 & $1.33(0.24)$ & $0.85(0.57)$ \\
\hline 10 & $1.09(0.38)$ & $0.72(0.70)$ \\
\hline 11 & $1.00(0.45)$ & $0.62(0.80)$ \\
\hline 12 & $1.14(0.34)$ & $0.82(0.62)$ \\
\hline
\end{tabular}

<표 3〉의 두 번째 열의 귀무가설은 KOSPI 지수 수익률이 공매도 지수를 선행하지 않는다는 것이며, 단기에서는 귀무가설을 기각하지 못한다. 하지만 시차가 4,5 인 경우 귀무가설을 기각하여 KOSPI 지수 수익률이 공매도 지수(SI)를 선행한다는 것을 확인할 수 있었다. 이 결과는 두 가지로 해석할 수 있다. 첫 번째는 시장에 공매도 거래자들 중 일부 추세 추종자(trend follower)인 비정보거래자가 존재하여 주가지수의 추세를 보고 일정 시점 후에 공매도 거래를 실행한다는 해석이다. 또 다른 해석은 시장 수익률이 충분히 하락한 이후 공매도 거래자들이 공매도한 주식을 갚기 위하여 솟커버(공매도 포지션 청산을 위한 주식 재매입)할 때 공매도 거래량이 감소하여 시장 수익률을 후행 한다는 것이다.

\section{2 내표본 예측회귀분석 결과}

<표 4>는 각 예측 변수들의 예측 기간에 따른 내표본 예측회귀분석 결과를 나타낸다. 각 열에는 1 개월 $(h=1), 3$ 개월 $(h=3), 6$ 개월 $(h=6), 9$ 개월( $h=9), 12$ 개월 $(h=12)$ 예측 회귀분석의 $\beta$ 추정치와 $R^{2}$ 값이 주어져 있다. 공매도 지수(SII)의 1 개월 예측 결과를 살펴 보면, 예측 회귀 모형의 $\hat{\beta}$ 추정치가 음의 값(-0.33)을 가지며 통계적으로 유의한 예측력을 갖는다. 즉, 공매도 지수가 1 표준편차 증가할 때 다음달의 리스크 프리미엄은 $33 \mathrm{bp}$ 감소 함을 의미하며, 이는 Miller(1977)의 정보거래가설을 지지하는 결과이다. 


\section{Short Interest and Market Risk Premium}

\section{〈표 4〉내표본 예측회귀분석 결과}

표는 다음 내표본 예측회귀모형의 $\beta$ 추정치와 $R^{2}$ 통계량을 나타낸다.

$$
r_{t: t+h}=\alpha+\beta x_{t}+\varepsilon_{t: t+h}, t=1, \ldots, T-h
$$

여기서 $r_{t: t+h}=\frac{r_{t+1}+\ldots+r_{t+h}}{\mathrm{~h}}, r_{t}$ 는 KOSPI 지수의 월별 로그 초과수익률을 나타낸다. $x_{t}$ 는 예측 변수를 의미하며 공매도 지수(SII)와 13 개 거시경제 및 시장 변수를 나타낸다. 각 예측 변수들은 표준편차가 1 이 되도록 표준화하였다. $\beta$ 추정치 아래의 대괄호는 이분산과 자기상관에 강건한 Newey-West $t$-통계량이다. $\mathrm{PC}+\mathrm{SII}$ 행은 거시경제 및 시장 변수로부터 구한 3 개의 주성분들과 공매도 지수를 설명 변수로 한 다중 예측회귀모형의 $\beta$ 추정치와 $R^{2}$ 통계량을, 4 factor $\mathrm{SII}$ 행은 기업특성 및 시장 요인(HML, MKT, SMB, MOM)과 공매도 지수(SII)를 설명 변수로 한 다중 예측회귀모형의 $\beta$ 추정치와 $R^{2}$ 통계량을 의미한다. 위첨자 ${ }^{*},{ }^{* *},{ }^{* * *}$ 는 각각 $10 \%, 5 \%, 1 \%$ 신뢰수준 하에서 통계적 으로 유의함을 나타낸다.

\begin{tabular}{|c|c|c|c|c|c|c|c|c|c|c|}
\hline & \multicolumn{2}{|c|}{$h=1$} & \multicolumn{2}{|c|}{$h=3$} & \multicolumn{2}{|c|}{$h=6$} & \multicolumn{2}{|c|}{$h=9$} & \multicolumn{2}{|c|}{$h=12$} \\
\hline & $\beta$ & $R^{2}$ & $\beta$ & $R^{2}$ & $\beta$ & $R^{2}$ & $\beta$ & $R^{2}$ & $\beta$ & $R^{2}$ \\
\hline$\overline{S I I}$ & $\begin{array}{c}-0.33^{* *} \\
{[-1.98]}\end{array}$ & $11.10 \%$ & $\begin{array}{c}-0.33^{* *} \\
{[-2.17]}\end{array}$ & $21.13 \%$ & $\begin{array}{c}-0.16^{* *} \\
{[-2.38]}\end{array}$ & $16.35 \%$ & $\begin{array}{r}-0.05 \\
{[-1.35]}\end{array}$ & $4.39 \%$ & $\begin{array}{r}-0.01 \\
{[-0.42]}\end{array}$ & $0.40 \%$ \\
\hline$D P$ & $\begin{array}{r}-0.02 \\
{[-0.13]}\end{array}$ & $0.03 \%$ & $\begin{array}{r}0.01 \\
{[0.08]}\end{array}$ & $0.03 \%$ & $\begin{array}{r}0.08 \\
{[0.92]}\end{array}$ & $4.34 \%$ & $\begin{array}{c}0.10^{*} \\
{[1.83]}\end{array}$ & $15.01 \%$ & $\begin{array}{c}0.10^{* * *} \\
{[2.66]}\end{array}$ & $23.00 \%$ \\
\hline$D Y$ & $\begin{array}{r}0.00 \\
{[0.03]}\end{array}$ & $0.00 \%$ & $\begin{array}{r}0.03 \\
{[0.29]}\end{array}$ & $0.34 \%$ & $\begin{array}{r}0.09 \\
{[1.11]}\end{array}$ & $5.40 \%$ & $\begin{array}{c}0.11^{* *} \\
{[1.99]}\end{array}$ & $15.96 \%$ & $\begin{array}{c}0.10^{* * * *} \\
{[2.75]}\end{array}$ & $23.49 \%$ \\
\hline$E P$ & $\begin{array}{c}0.17^{* *} \\
{[2.28]}\end{array}$ & $2.75 \%$ & $\begin{array}{c}0.11^{* *} \\
{[1.99]}\end{array}$ & $3.35 \%$ & $\begin{array}{c}0.08^{*} \\
{[1.75]}\end{array}$ & $3.78 \%$ & $\begin{array}{r}0.03 \\
{[0.86]}\end{array}$ & $1.59 \%$ & $\begin{array}{r}0.01 \\
{[0.40]}\end{array}$ & $0.34 \%$ \\
\hline$D E$ & $\begin{array}{r}-0.14 \\
{[-1.29]}\end{array}$ & $1.83 \%$ & $\begin{array}{r}-0.10 \\
{[-1.08]}\end{array}$ & $2.77 \%$ & $\begin{array}{r}-0.06 \\
{[-0.97]}\end{array}$ & $2.05 \%$ & $\begin{array}{r}0.00 \\
{[-0.08]}\end{array}$ & $0.01 \%$ & $\begin{array}{r}0.02 \\
{[0.72]}\end{array}$ & $1.07 \%$ \\
\hline$R V O L$ & $\begin{array}{r}0.04 \\
{[0.31]}\end{array}$ & $0.17 \%$ & $\begin{array}{r}0.05 \\
{[0.42]}\end{array}$ & $0.63 \%$ & $\begin{array}{r}0.07 \\
{[0.93]}\end{array}$ & $3.28 \%$ & $\begin{array}{c}0.10^{*} \\
{[1.85]}\end{array}$ & $12.18 \%$ & $\begin{array}{c}0.10^{* * * *} \\
{[3.00]}\end{array}$ & $24.64 \%$ \\
\hline NTIS & $\begin{array}{r}0.07 \\
{[0.47]}\end{array}$ & $0.45 \%$ & $\begin{array}{r}0.08 \\
{[0.61]}\end{array}$ & $1.72 \%$ & $\begin{array}{r}0.11 \\
{[1.33]}\end{array}$ & $7.17 \%$ & $\begin{array}{c}0.11^{* *} \\
{[2.13]}\end{array}$ & $17.52 \%$ & $\begin{array}{c}0.11^{* * *} \\
{[3.20]}\end{array}$ & $27.38 \%$ \\
\hline$T B L$ & $\begin{array}{c}-0.27^{* *} \\
{[-2.00]}\end{array}$ & $7.40 \%$ & $\begin{array}{c}-0.25^{* *} \\
{[-2.07]}\end{array}$ & $17.30 \%$ & $\begin{array}{r}-0.12 \\
{[-1.45]}\end{array}$ & $9.32 \%$ & $\begin{array}{r}-0.03 \\
{[-0.45]}\end{array}$ & $0.86 \%$ & $\begin{array}{r}0.01 \\
{[0.18]}\end{array}$ & $0.11 \%$ \\
\hline$L T Y$ & $\begin{array}{r}-0.07 \\
{[-0.45]}\end{array}$ & $0.50 \%$ & $\begin{array}{r}-0.07 \\
{[-0.49]}\end{array}$ & $1.24 \%$ & $\begin{array}{r}-0.01 \\
{[-0.07]}\end{array}$ & $0.02 \%$ & $\begin{array}{r}0.04 \\
{[0.73]}\end{array}$ & $2.41 \%$ & $\begin{array}{r}0.06 \\
{[1.41]}\end{array}$ & $8.66 \%$ \\
\hline$T M S$ & $\begin{array}{c}0.25^{* * *} \\
{[2.69]}\end{array}$ & $6.45 \%$ & $\begin{array}{c}0.22^{* * *} \\
{[2.85]}\end{array}$ & $13.89 \%$ & $\begin{array}{c}0.15^{* * *} \\
{[2.92]}\end{array}$ & $14.81 \%$ & $\begin{array}{c}0.10^{* * *} \\
{[3.03]}\end{array}$ & $15.64 \%$ & $\begin{array}{c}0.09^{* * *} \\
{[3.47]}\end{array}$ & $21.10 \%$ \\
\hline$D F Y$ & $\begin{array}{c}0.36^{* * *} \\
{[3.74]}\end{array}$ & $12.86 \%$ & $\begin{array}{c}0.29^{* * *} \\
{[2.50]}\end{array}$ & $23.75 \%$ & $\begin{array}{r}0.12 \\
{[1.08]}\end{array}$ & $9.31 \%$ & $\begin{array}{r}0.01 \\
{[0.10]}\end{array}$ & $0.09 \%$ & $\begin{array}{r}-0.02 \\
{[-0.49]}\end{array}$ & $1.47 \%$ \\
\hline INFL & $\begin{array}{r}-0.04 \\
{[-0.35]}\end{array}$ & $0.13 \%$ & $\begin{array}{r}0.04 \\
{[0.76]}\end{array}$ & $0.58 \%$ & $\begin{array}{r}-0.02 \\
{[-0.43]}\end{array}$ & $0.23 \%$ & $\begin{array}{r}-0.02 \\
{[-0.62]}\end{array}$ & $0.65 \%$ & $\begin{array}{r}-0.02 \\
{[-0.59]}\end{array}$ & $0.55 \%$ \\
\hline$B M$ & $\begin{array}{c}0.27^{* * *} \\
{[3.05]}\end{array}$ & $7.49 \%$ & $\begin{array}{c}0.26^{* * *} \\
{[3.57]}\end{array}$ & $20.35 \%$ & $\begin{array}{c}0.24^{* * *} \\
{[4.80]}\end{array}$ & $39.16 \%$ & $\begin{array}{c}0.18^{* * *} \\
{[5.97]}\end{array}$ & $47.21 \%$ & $\begin{array}{c}0.14^{* * *} \\
{[6.48]}\end{array}$ & $45.60 \%$ \\
\hline$P C+S I I$ & $\begin{array}{c}-0.28^{* * *} \\
{[-2.90]}\end{array}$ & $27.43 \%$ & $\begin{array}{c}-0.22^{* * *} \\
{[-5.23]}\end{array}$ & $63.47 \%$ & $\begin{array}{c}-0.14^{* * * *} \\
{[-4.68]}\end{array}$ & $58.94 \%$ & $\begin{array}{c}-0.06^{* *} \\
{[-2.13]}\end{array}$ & $52.36 \%$ & $\begin{array}{r}-0.02 \\
{[-1.18]}\end{array}$ & $56.96 \%$ \\
\hline 4factor + SII & $\begin{array}{c}-0.31^{* *} \\
{[-1.89]}\end{array}$ & $9.07 \%$ & $\begin{array}{c}-0.25^{* *} \\
{[-2.06]}\end{array}$ & $20.46 \%$ & $\begin{array}{c}-0.14^{* *} \\
{[-2.24]}\end{array}$ & $20.53 \%$ & $\begin{array}{r}-0.05 \\
{[-1.42]}\end{array}$ & $7.70 \%$ & $\begin{array}{r}-0.00 \\
{[-0.21]}\end{array}$ & $4.31 \%$ \\
\hline
\end{tabular}

1 개월 단기 예측의 경우 본질적으로 예측불가능한 요소가 많이 포함되어 있어 장기 예측과 비교하면 $R^{2}$ 값이 상대적으로 낮다. Campbell and Thompson(2007)는 월별 $R^{2}$ 값이 0.5\% 이상이면 경제적으로 유의한 예측력을 갖는다고 주장하였으며, 공매도 지수(SII)의 $R^{2}$ 값은 
한국증권학회지 제 48 권 5호 (2019)

$11.10 \%$ 로 경제적으로 유의한 값이다. 3 개월과 6 개월 예측 결과를 살펴보면, 공매도 지수 (SII)의 $\hat{\beta}$ 추정치는 각각 $-0.33,-0.16$ 으로 다음 기의 리스크 프리미엄과 유의한 음의 관계를 갖는다. 반면, 장기(9개월 및 12 개월) 예측 결과를 살펴보면, 공매도 지수의 통계적 유의성이 사라진다.

<표 4>의 $\mathrm{PC}+\mathrm{SII}$ 행에서는 3 가지 주성분을 통제한 공매도 지수(SII)의 예측회귀분석 결과를 제시하고 있다. 결과를 살펴보면 1 개월, 3 개월, 6 개월 예측 $\beta_{S I I}$ 값은 각각 -0.28 , $-0.22,-0.14$ 이고, $1 \%$ 신뢰수준 하에서 유의한 값이다. ${ }^{4)}$ 단기에서 장기로 갈수록 $\beta_{S I I}$ 의 절대값이 감소하는데, 공매도 거래량 변화에 따른 미래 시장 리스크 프리미엄의 반응성이 감소함을 의미한다. 다음으로 주성분을 통제하기 전후의 공매도 지수(SII) 모형 예측 회귀 분석의 $R^{2}$ 를 비교해보면 변수 통제 전 공매도 지수(SII)의 설명력은 단기 $\left(R^{2}=11.10 \%\right)$ 에서 장기 $\left(R^{2}=0.4 \%\right)$ 로 갈수록 크게 감소하는 반면, 거시경제 및 시장 변수를 포함한 모형의 장기 설명력 $\left(R^{2}=56.96 \%\right)$ 은 여전히 높은 것을 확인할 수 있다. 그러므로 거시경제 및 시장 변수와 공매도 지수(SII)를 함께 포함하는 예측의 경우 단기에서는 공매도 지수(SII), 장기 에서는 거시경제 및 시장 변수가 중요한 것을 알 수 있다.

4 factor+SII 행에서는 기업 특성 및 시장 요인들을 통제한 공매도 지수(SII)의 예측회귀 분석 결과를 제시하고 있다. 1 개월, 3 개월, 6 개월 $\beta_{S I I}$ 의 값을 살펴보면 각각 $-1.89,-2.06$, -2.24로, 기업특성 및 시장 요인들을 통제한 후에도 공매도 지수는 시장 리스크 프리미엄 에 대한 유의한 예측력을 갖는다. $\mathrm{PC}+\mathrm{SII}$ 의 결과와 유사하게 단기에서 장기로 갈수록 $\beta_{S I I}$ 의 절대값이 감소하며, 공매도 거래량 변화에 따른 미래 시장 리스크 프리미엄의 반응성이 감소한다.

\section{3 외표본 예측회귀분석 결과}

<표 5>는 각 예측 변수들의 예측 기간에 따른 외표본 예측회귀분석 결과를 나타낸다. 각 열에는 1 개월( $h=1), 3$ 개월( $h=3), 6$ 개월 $(h=6)$, 9개월 $(h=9), 12$ 개월( $h=12), 15$ 개월 ( $h=15), 18$ 개월 $(h=18)$ 예측 회귀분석의 $R_{o s}^{2}$ 값이 주어져 있다. 공매도 지수(SII)의 단기 (1개월, 3 개월, 6 개월) 예측 $R_{o s}^{2}$ 는 각각 $5.24 \%, 15.59 \%, 15.89 \%$ 로 예측력이 뛰어나다. 그러나 장기(12개월, 15 개월, 18 개월) $R_{o s}^{2}$ 값은 각각 $-2.28 \%,-0.90 \%,-0.88 \%$ 로 예측력을 상실한다. 그러므로 기존 장기 예측력이 높은 거시경제 및 시장 변수들과 달리, 공매도 지수(SII)는 단기에서의 예측력이 높다는 본 연구의 가설을 지지한다. 4factor+ SII 행에서는 기업 특성 및 시장 요인들을 통제한 외표본 예측회귀분석 결과이다. $R_{o s}^{2}$ 를 살펴보면, 단기(1개월, 3 개월, 6개월) $R_{o s}^{2}$ 는 각각 $0.60 \%, 27.21 \%, 15.93 \%$ 로 예측력이 뛰어날 뿐만 아니라, 장기(12개월,

4) $P C$ 를 통제한 9 개월 예측 $(h=9)$ 회귀분석에서 SII의 계수를 보면 단변량 분석에서와 비교해 절대 값이 커지고 유의해진 것을 확인할 수 있는데, 이는 단변량 분석에서 누락 변수 편의(Omitted variable bias)가 발생했기 때문으로 해석할 여지가 있다. 
15 개월, 18 개월) $R_{o s}^{2}$ 는 각각 $12.46 \%, 10.84 \%, 13.05 \%$ 로 장기 예측력도 향상된 결과를 확인할 수 있다.

\section{〈표 5〉외표본 분석결과}

표는 외표본 예측회귀모형의 외표본 $R_{O S}^{2}$ 를 나타낸다. 해당 회귀모형의 종속변수는 KOSPI 초과 수익률, 설명변수는 공매도 지수(SII)와 13 개 거시경제 및 시장 변수이다. 외표본 $R_{O S}^{2}$ 는 다음과 같이 구할 수 있다.

$$
R_{O S}^{2}=1-\frac{M S F E_{\text {pred }}}{M S F E_{\text {null }}}
$$

여기서, $M S F E_{\text {pred }}, M S F E_{\text {nul }}$ 은 각각 예측 회귀분석의 평균 제곱 예측오차와 과거 평균 모형의 평균 제곱 예측오차를 나타낸다. 외표본 $R_{O S}^{2}$ 의 통계적 검정을 위해, McCracken(2004)이 제안한 $F$ 통계량을 사용하였다.

$$
F_{\text {MSFE }}=(T-h+1) \times\left(\frac{M S F E_{\text {null }}-M S F E_{\text {pred }}}{M S F E_{\text {pred }}}\right)
$$

단, T는 관측치의 수, $h$ 는 예측 기간을 의미한다. 위 $F_{M S F E}$ 통계량을 활용하여, 아래의 가설을 검정한다.

$$
H_{0}: R_{O S}^{2} \leq 0 \text { against } H_{A}: R_{O S}^{2}>0
$$

마지막 행의 4 factor+SII는 기업특성 및 시장 요인 $(M K T, S M B, H M L, M O M)$ 을 통제한 SII의 외표본 $R_{O S}^{2}$ 를 의미한다. 위첨자 ${ }^{*},{ }^{* *}{ }^{* * *}$ 는 각각 $10 \%, 5 \%, 1 \%$ 신뢰수준 하에서 통계적으로 유의함을 나타낸다.

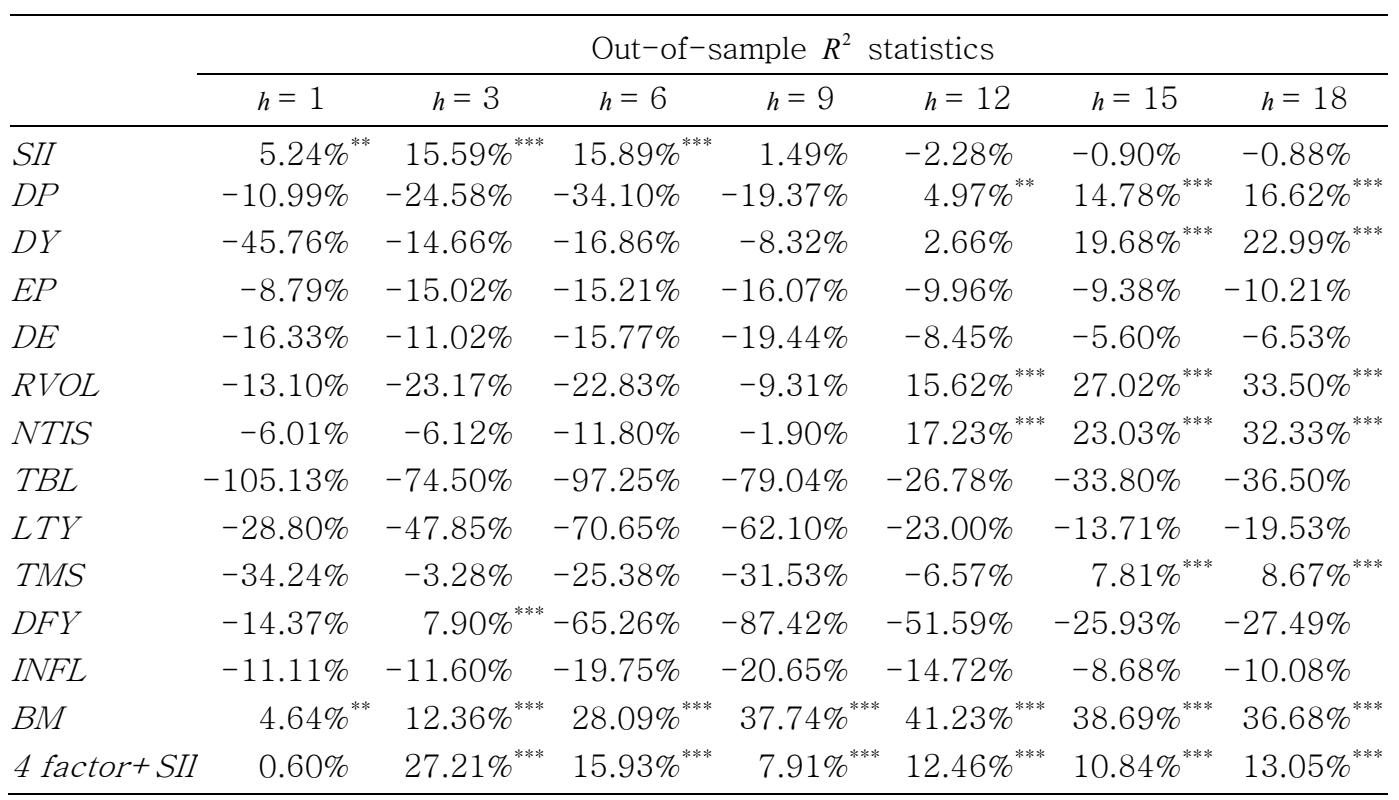




\section{4 자산배분 성과분석}

본 장에서는 공매도 지수(SII)의 경제적 가치를 평가하기 위해 자산배분 측면에서 공매도 지수(SII)의 예측력을 분석하였다. 〈표 6>은 예측변수들의 예측 기간에 따른 외표본 확실성 등가 수익률 이익을 나타낸다. 확실성 등가 수익률 이익은 기준 포트폴리오(과거평균모형) 대신에 예측회귀모형을 사용하기 위해 투자자들이 기꺼이 지불할 추가 비용을 의미하며, 값이 클수록 예측 성과가 좋음을 의미한다. 1 개월 투자 기준으로 $S I I$ 의 확실성 등가 수익이 세 번째로 좋은 성과를 보였고(0.59), 3개월 투자 기준으로는 $S I I$ 의 성과가 가장 좋았다 (0.21). 반면 중장기 투자 $h=9, h=12)$ 의 경우 상대적으로 공매도 지수(SII) 포트폴리오의 확실성 등가 수익이 낮은 것을 확인할 수 있다.

〈표 6〉확실성 등가 수익률 이익 분석

표는 확실성 등가 수익률 이익을 나타낸다. 확실성 등가 수익률 이익은 다음과 같이 구할 수 있다.

$$
\mathrm{CER}=E\left[R_{p}\right]-0.5 \gamma \sigma_{p}
$$

여기서, $\mathrm{E}\left[R_{p}\right]$ 는 해당 포트폴리오의 평균 수익률, $r_{f}$ 는 무위험수익률, 그리고 $\sigma_{p}$ 는 포트폴리오의 표준편차를 나타낸다.

\begin{tabular}{lrrrrr}
\hline & $h=1$ & $h=3$ & $h=6$ & $h=9$ & $h=12$ \\
\hline SII & 0.59 & 0.21 & 0.05 & 0.03 & 0.00 \\
$D P$ & -0.36 & 0.07 & 0.09 & -0.05 & -0.10 \\
$D Y$ & 0.53 & -0.05 & 0.03 & -0.39 & -0.12 \\
$E P$ & 0.42 & 0.20 & 0.11 & 0.06 & -0.02 \\
$D E$ & 0.64 & -0.40 & 0.14 & 0.06 & -0.02 \\
RVOL & -0.08 & 0.10 & 0.09 & 0.07 & -0.02 \\
NTIS & 0.00 & 0.04 & 0.12 & -0.03 & -0.20 \\
TBL & 0.70 & -0.15 & 0.13 & 0.07 & 0.01 \\
LTY & 0.38 & 0.19 & 0.07 & 0.07 & -0.01 \\
TMS & -0.09 & -1.33 & 0.02 & -0.06 & -0.11 \\
DFY & 0.31 & -0.64 & -0.02 & -0.37 & -0.10 \\
INFL & -0.76 & -0.46 & 0.08 & 0.07 & -0.06 \\
BM & 0.38 & 0.13 & 0.11 & 0.06 & -0.07 \\
\hline
\end{tabular}

<표 7>은 공매도 지수(SII)와 기존 거시경제 및 시장 변수의 정보를 활용하여 자산 배분한 포트폴리오의 샤프 비율을 나타낸다. DeMiguel et al.(2007)에 의하면 평균-분산 모형의 경우 단기에서 입력 변수인 리스크 프리미엄의 추정 오차가 상대적으로 크고 장기에서는 그 추정 오차가 줄어든다. 따라서 일반적으로 단기 $(h=1, h=3)$ 에서는 상대적으로 샤프 비율이 낮고, 장기로 갈수록 높아진다. 예를 들어 $D P, D Y, I N F L$ 의 경우 단기 $(h=1, h=3)$ 자산배분에서 음의 샤프 비율을 가지나 장기 $(h=6, h=9, h=12)$ 자산배분의 경우 양의 샤프 비율을 가진다. 반면, 공매도 지수(SII)를 활용한 자산배분모형은 단기에서 자산배분의 성과가 뛰어나나, 장기에서 자산배분의 성과가 떨어진다. 이 역시, 시장 리스크 프리미엄에 
대한 공매도 지수(SII)의 단기 예측력이 상대적으로 뛰어나기 때문이다.

〈표 7〉샤프 비율 분석

표는 자산배분 포트폴리오의 샤프비율을 나타낸다. 샤프비율은 다음과 같이 구할 수 있다.

$$
\text { Sharpe ratio }=\frac{E\left[R_{p}\right]-r_{f}}{\sigma_{p}}
$$

여기서, $\mathrm{E}\left[R_{p}\right]$ 는 해당 포트폴리오의 평균 수익률, $r_{f}$ 는 무위험수익률, 그리고 $\sigma_{p}$ 는 포트폴리오의 표준편차를 나타낸다.

\begin{tabular}{|c|c|c|c|c|c|}
\hline & $h=1$ & $h=3$ & $h=6$ & $h=9$ & $h=12$ \\
\hline$S I I$ & 0.76 & 0.50 & -0.07 & -0.04 & 0.47 \\
\hline$D P$ & -0.46 & -0.32 & 0.34 & 0.44 & 0.49 \\
\hline$D Y$ & 0.40 & -0.38 & 0.33 & 0.41 & 0.46 \\
\hline$E P$ & 0.20 & 0.43 & 0.46 & 0.51 & 0.54 \\
\hline$D E$ & 0.88 & 0.50 & 0.64 & 0.52 & 0.54 \\
\hline$R V O L$ & 0.05 & -0.09 & 0.38 & 0.50 & 0.54 \\
\hline NTIS & -0.78 & -0.32 & 0.57 & 0.44 & 0.32 \\
\hline$T B L$ & 0.92 & 0.50 & 0.62 & 0.47 & 0.51 \\
\hline$L T Y$ & 0.14 & 0.43 & 0.26 & 0.48 & 0.52 \\
\hline$T M S$ & -0.17 & 0.36 & 0.01 & -0.11 & 0.06 \\
\hline$D F Y$ & 0.71 & 0.46 & 0.50 & 0.44 & 0.54 \\
\hline INFL & -0.49 & -0.33 & 0.24 & 0.50 & 0.56 \\
\hline$B M$ & -0.25 & 0.48 & 0.63 & 0.49 & 0.51 \\
\hline Historical mean & -0.60 & -0.29 & -0.20 & -0.03 & 0.47 \\
\hline
\end{tabular}

\section{5 주가 수익률 분해 분석 결과}

본 장에서는 미래 주가 수익률을 3 가지 요소로 분해하여 공매도 지수(SII)의 예측력에 관한 핵심 동인(動因)을 분석하고자 한다. 먼저 주가 수익률은 식 (19)와 같이 기대수익률, 할인율(Discount rate) 그리고 현금흐름 뉴스(Cash flow news)로 분해할 수 있음이 알려져 있다.

$$
r_{t+1}=E_{t} r_{t+1}+\varphi_{t+1}^{C F}-\varphi_{t+1}^{D R}
$$

Campbell(1991)과 Campbell and Ammer(1993)의 방법론을 활용하면 VAR 분석을 통해 예상치 못한 주가수익률 충격 $\left(\varphi_{t+1}^{r}=r_{t+1}-E_{t} r_{t+1}\right)$, 현금흐름 정보 $\left(\varphi_{t+1}^{C F}\right)$, 할인율 정보 $\left(\varphi_{t+1}^{D R}\right)$, 기대 수익률에 대한 근사치를 구할 수 있다. 그리고 각각의 추정치에 대해 식 (20), 식 (21), 식 (22)와 같은 예측 회귀분석을 진행하여, 공매도 지수(SII)가 미래 현금흐름 뉴스에 대한 예측력을 갖는지 혹은 할인율 뉴스에 대한 예측력을 갖는지 확인할 수 있다.

$$
\begin{gathered}
\widehat{E_{t} r_{t+1}}=\alpha_{E}+\beta_{E} S I I_{t}+\varepsilon_{t+1}^{E} \\
\widehat{\varphi_{t+1}^{C F}}=\beta_{C F} S I I_{t}+\varepsilon_{t+1}^{C F}
\end{gathered}
$$


한국증권학회지 제48권 5호 (2019)

$$
\widehat{\varphi_{t+1}^{D R}}=\beta_{D R} S I I_{t}+\varepsilon_{t+1}^{D R}
$$

이 때, 식 (3)에서의 공매도 지수(SII)의 회귀 계수를 식 (23)과 같이 기대수익률 $\left(\beta_{E}\right)$, 현금흐름 정보 $\left(\beta_{C F}\right)$, 할인율 정보 $\left(\beta_{D R}\right)$ 로 분해할 수 있다.

$$
\beta=\beta_{E}+\beta_{C F}-\beta_{D R}
$$

<표 8>은 공매도 지수(SII)의 기대수익률, 현금흐름 뉴스, 할인율 뉴스에 대한 공매도 지수(SII)의 예측력을 의미한다. 표의 $\beta_{k}$ 는 다음 예측회귀모형의 OLS 추정치를 의미한다.

$$
y_{t+1}=\alpha_{k}+\beta_{k} S I I_{t}+\varepsilon_{k, t+}, t=1, \ldots, T-1
$$

여기서, $y_{t+1}$ 는 월별 KOSPI 로그 수익률에서부터 추정된 $\widehat{E_{t} r_{t+1}}, \widehat{\varphi_{t+1}^{C F}}, \widehat{\varphi_{t+1}^{D R}}$ 이고, $S I_{t}$ 는 공매도 지수(SII)를 의미한다. VAR 모형 추정 시 $D P$ 를 항상 통제 변수로 사용하였는데, 이는 Engsted et al.(2012)이 VAR 모형에서 현금흐름 뉴스와 할인율 뉴스를 추정하는데 $D P$ 가 중요한 역할을 한다는 것을 밝혔기 때문이다.

〈표 8〉시장 수익률 분해를 통한 예측 회귀 분석 추정 결과

표의 $\beta_{k}$ 는 다음 예측회귀모형의 OLS 추정치를 의미한다.

$$
y_{t+1}=\alpha_{k}+\beta_{k} S I I_{t}+\varepsilon_{k, t+1}, t=1, \ldots, T-1
$$

여기서, $y_{t+1}$ 는 월별 KOSPI 로그 수익률에서부터 추정된 $\widehat{E_{t} r_{t+1}}, \widehat{\varphi_{t+1}^{C F}}, \widehat{\varphi_{t+1}^{D N}}$ 이고, $S I I_{t}$ 는 공매도 지 수(SII)를 의미한다. $\widehat{E_{t} r_{t+1}}, \widehat{\varphi_{t+1}^{C F}}, \widehat{\varphi_{t+1}^{\text {DP }}}$ 는 각각 Campbell(1991)과 Campbell and Ammer(1993) 의 방법론을 활용하여 추정하였다. 모든 VAR 분석에는 기본적으로 KOSPI 로그 수익률과 $D P$ 가 포함되 어 있으며, 여기에 거시경제 및 시장 변수를 개별적으로 추가하여 분석하였다. $\beta_{E}, \beta_{C F}, \beta_{D R}$ 는 각각 기대수익률 $\left(\widehat{E_{t} r_{t+1}}\right)$ 의 추정치, 현금흐름 뉴스 $\left(\widehat{\varphi_{t+1}^{C F}}\right)$ 의 추정치, 그리고 할인율 뉴스 $\left(\varphi_{t+1}^{D R}\right)$ 를 종속 변수로 한 회귀분석의 회귀 계수를 의미한다. 현금흐름 뉴스와 할인율 뉴스에 관한 예측 회귀 모형의 경우, 절편 $\left(\alpha_{k}\right)$ 을 0 으로 설정하고 $\beta_{C F}, \beta_{D R}$ 를 추정하였다. 각각의 회귀계수 추정치 아래의 대 괄호는 이분산과 자기상관에 강건한 $t$-통계량을 나타낸다. 위첨자 * ${ }^{* *},{ }^{* * *}$ 는 각각 $10 \%, 5 \%, 1 \%$ 신뢰수준 하에서 통계적으로 유의함을 나타낸다.

\begin{tabular}{llcc}
\hline \multicolumn{1}{c}{ VAR 추가 변수 } & \multicolumn{1}{c}{$\beta_{E}$} & $\beta_{C F}$ & $\beta_{D R}$ \\
\hline$D P$ only & $-0.02[-2.89]^{* * *}$ & $-0.33[-1.97]^{*}$ & $-0.01[-1.95]^{*}$ \\
$D Y$ & $-0.02[-2.88]^{* * *}$ & $-0.33[-1.94]^{*}$ & $-0.01[-1.93]^{* *}$ \\
$E P$ & $-0.02[-0.82]$ & $-0.31[-1.98]^{* *}$ & $0.00[0.16]$ \\
$D E$ & $-0.07[-3.45]^{* * *}$ & $-0.26[-1.53]$ & $0.00[0.59]$ \\
$B M$ & $-0.15[-2.14]^{* *}$ & $-0.16[-1.69]^{*}$ & $0.02[0.67]$ \\
NTIS & $-0.02[-1.24]$ & $-0.32[-1.95]^{*}$ & $-0.01[-2.12]^{* *}$ \\
$T B L$ & $-0.03[-0.45]$ & $-0.31[-2.57]^{* *}$ & $-0.01[-1.65]$ \\
LTY & $-0.02[-1.75]^{*}$ & $-0.32[-2.01]^{* *}$ & $-0.01[-1.93]^{* *}$ \\
$T M S$ & $-0.01[-0.23]$ & $-0.33[-2.21]^{* *}$ & $-0.01[-2.66]^{* * *}$ \\
$D F Y$ & $-0.06[-0.59]$ & $-0.27[-2.75]^{* * *}$ & $0.00[-0.02]$ \\
\hline
\end{tabular}


Short Interest and Market Risk Premium

\begin{tabular}{lccc}
\hline INFL & $-0.02[-2.93]^{* * *}$ & $-0.32[-1.95]^{*}$ & $-0.01[-1.42]$ \\
RVOL & $-0.02[-2.12]^{* *}$ & $-0.32[-1.91]^{*}$ & $-0.01[-2.29]^{* *}$ \\
\hline \multicolumn{1}{r|}{ 절대값을 기준으로 모든 예측회귀분석에서 $\beta_{C F}$ 추정치가 가장 크며, $D E$ 를 추가 통제 변수로 }
\end{tabular}
사용한 경우를 제외하고 항상 유의하다. 이는 시장전반의 공매도 거래와 미래 현금흐름 뉴스가 음의 상관관계를 가지며, 그 영향력도 가장 크다는 것을 의미한다. 결론적으로 공매도 거래자는 미래 현금흐름 뉴스에 대한 정보를 가진 정보거래자이며 공매도 지수(SII)의 주가지수 예측력이 미래 현금흐름 뉴스 정보에 기인한 것임을 시사한다.

\section{5. 결론 및 시사점}

본 연구에서는 한국시장에 존재하는 주식, ETFs, 리츠의 공매도 정보를 활용하여 시장 전반의 공매도 지수(SII)를 구축하였다. 기존 공매도와 주가수익률 간의 관계를 분석한 국내 연구의 경우 대부분 개별 기업을 중심으로 분석한 반면, 본 연구에서는 시장 전반의 공매도 정보와 한국 금융 시장의 전반의 리스크 프리미엄간의 관계를 분석하였다. 공매도 지수의 시장예측력을 확인하기 위해 그레인져 인과관계 분석, 예측회귀분석, 자산배분 분석 등 다방면의 분석을 시행했으며, 공매도 지수(SII)의 단기 예측력이 통계적, 경제적으로 모두 유의한 것을 확인하였다. 외표본 예측회귀분석과 자산배분 분석결과, 시장 리스크 프리미엄에 대한 공매도 지수(SII)의 예측력은 단기에서 뛰어나고 장기에서 약화되는 것을 확인하였다. 일반적으로 거시경제 및 시장 변수들의 단기 예측력이 낮은 것을 고려하면 공매도 지수(SII)의 높은 단기 시장 리스크 프리미엄 예측은 경제적인 가치를 갖는다. 시장 수익률 분해를 통한 예측회귀분석 결과, 공매도 거래자는 미래 시장전반에 관한 현금흐름 뉴스를 취득하는데 이점이 있었다. 또한, 기존 공매도 관련 연구결과에 따르면, 공매도 거래자는 미래 개별 기업에 관한 정보를 취득하는 능력이 있다. 두 결과를 종합하면, 공매도 거래자는 자산가격에 대한 개별 고유(Idiosyncratic)의 요소뿐만 아니라, 체계적(Systemic) 요소를 평가하는 정보 거래자임을 시사한다.

단기에서 공매도 지수(SII)의 예측력의 근원은 정보 획득 및 리스크 감내에 대한 보상, 그리고 차익거래 제약(Limit to arbitrage)의 관점으로 접근할 수 있다. 첫째, 정보의 관점에서 시장 리스크 프리미엄에 대한 공매도 지수(SII)의 예측력은 공매도 거래자가 미래 시장전반의 정보를 획득하고 분석하는 행위에 대한 보상으로 해석할 수 있다. Grossman and Stiglitz(1980)의 연구결과에 따르면, 공매도 거래자는 미래 시장 정보를 얻고, 이를 해석하는데 보상을 받는다. 그러나, 거래소에서 공매도 거래가 공식적으로 발표되는 경우에도 투자자들은 시장 전반의 공매도 거래정보를 적극적으로 활용하지 않는데, 그 이유는 최근까지 공매도 거래 자료가 전자 공시 되지 않았기 때문이다. 특히, 한국 시장의 경우, 개별기업에 대한 공매도 자료는 2008년 이후 공시되었기 때문에 전체 기업에 대한 공매도 자료를 모으기 위해서는 상당한 비용이 소모된다. 둘째, 공매도를 통한 차익거래 기회(Arbitrage opportunity) 실현 시 시장 
한국증권학회지 제48권 5호 (2019)

마찰 요인에 의한 위험이 존재하는데, 시장 리스크 프리미엄에 대한 공매도 지수(SII)의 예측력은 이에 대한 보상으로 해석할 수 있다(Shleifer and Vishny, 1997). Engelberg et al. (2018)에 따르면, 공매도 거래자는 증권대차시장에서 주식을 빌릴 때, 다양한 공매도 고유의 위험에 직면한다. 예를 들면, 대차시장에서 주식 대출이 취소되거나, 시장이나 개별 기업의 상황에 따라 대출 비용이 크게 변동할 위험이 있다. 이로 인하여, 시장에서 차익거래의 기회가 존재하여도, 투자자는 공매도 거래를 통해 차익을 얻는데 위험을 수반한다. 공매도 지수(SII)의 예측력은 이러한 리스크에 대한 보상으로 해석할 수 있다. 또한, 시장에 공매도 제약이 존재하는 경우, 투자자는 공매도 거래로 인한 이익이 비용 이상일 때만 공매도 거래를 실시한다. 따라서 차익거래의 제약이 존재한다면, 정보거래자들의 시장참여가 제한되어 시장에 정보가 완벽히 반영되지 않을 수 있다. 실제 한국 시장에서는 공매도 거래가 활발 하지 않으며, 공매도 거래가 가장 많았던 2008년 7월에도 시장 전체의 발행주식수 대비 공매도 거래의 비율은 $0.16 \%$ 로 낮은 수준이었다. Lamont and Stein(2004)는 IT 버블 기간 동안(1998년 2000년)에 미국 주식시장에서 발생한 공매도 거래가 시장전반의 가격 괴리를 정상가격으로 되돌리는데 부족함을 지적하였다. 같은 맥락에서 한국 시장의 전반적인 공매도 거래량은 시장에서 발생하는 가격 괴리를 진정한 가격으로 되돌리는데 부족하다고 볼 수 있다. 해소되지 못한 가격 괴리는 결국 미래에 실현되기 때문에, 시장 전반의 공매도 정보인 공매도 지수(SII)는 미래 시장 수익률에 대한 예측력을 가지게 된다.

본 연구가 시사하는 바는 다음과 같다. 먼저, 시장에서 가격 괴리가 해소되는 속도는 미국 시장에 비해 한국 시장이 보다 빠르다. Rapach et al.(2016)의 연구결과에 따르면, 미국 에서는 공매도 지수의 예측력이 시간이 지나도 지속되는 반면, 한국 시장의 경우 단기 예측력은 뛰어나나 장기에서의 예측력은 사라진다. 이는 한국 시장의 투자자들이 공매도 거래에 기민하게 반응한 결과 시장에서의 가격 괴리가 빠르게 해소되어 장기 예측력을 잃는 것으로 해석할 수 있다. 나아가 금융당국의 공매도 제약 완화 정책을 제안할 수 있다. 공매도 제약은 정보거래자의 시장 참여를 막아, 시장의 정보효율성을 저해할 가능성이 있다. 반면, 적절한 공매도 제약 완화는 정보거래자의 정보를 시장에 반영하여, 가격 괴리 해소를 도울 수 있다. 
Short Interest and Market Risk Premium

\section{References}

Akbas, F., E. Boehmer, B. Erturk, and S. M. Sorescu, 2013, Short interest, returns, and fundamentals, Available at SSRN: https://ssrn.com/abstract=2216919.

Ang, A., and G. Bekaert, 2006, Stock return predictability: Is it there?, Review of Financial Studies, Vol. 20 (3), pp. 651-707.

Asquith, P., P. A. Pathak, and J. R. Ritter, 2005, Short interest, institutional ownership, and stock returns, Journal of Financial Economics, Vol. 78 (2), pp. 243-276.

Boehmer, E., C. M. Jones, and X. Zhang, 2008, Which shorts are informed?, Journal of Finance, Vol. 63 (2), pp. 491-527.

Campbell, J. Y., 1991, A variance decomposition for stock returns, Economic Journal, Vol. 101, pp. 157-179.

Campbell, J. Y., and J. Ammer, 1993, What moves the stock and bond markets? A variance decomposition for long-term asset returns, Journal of Finance, Vol. 48 (1), pp. 3-37.

Campbell, J. Y., and S. B. Thompson, 2007, Predicting excess stock returns out of sample: Can anything beat the historical average?, Review of Financial Studies, Vol. 21 (4), pp. 1509-1531.

Carhart, M. M., 1997, On persistence in mutual fund performance, Journal of Finance, Vol. 52 (1), pp. 57-82.

Chang, E. C., J. W. Cheng, and Y. Yu, 2007, Short-sales constraints and price discovery: Evidence from the Hong Kong market, Journal of Finance, Vol. 62 (5), pp. 2097-2121.

Christophe, S. E., M. G. Ferri, and J. Hsieh, 2010, Informed trading before analyst downgrades: Evidence from short sellers, Journal of Financial Economics, Vol. 95 (1), pp. 85-106.

Christophe, S. E., M. G. Ferri, and J. J. Angel, 2004, Short-selling prior to earnings announcements, Journal of Finance, Vol. 59 (4), pp. 1845-1876.

Cochrane, J. H., 2008, The dog that did not bark: A defense of return predictability, Review of Financial Studies, Vol. 21 (4), pp. 1533-1575.

Daske, H., S. A. Richardson, and A. Tuna, 2005, Do short sale transactions precede bad news events? Available at SSRN: https://ssrn.com/abstract=722242.

DeMiguel, V., L. Garlappi, and R. Uppal, 2007, Optimal versus naive diversification: How inefficient is the 1/n portfolio strategy?, Review of Financial Studies, Vol. 22 (5), pp. 1915-1953.

Desai, H., K. Ramesh, S. R. Thiagarajan, and B. V. Balachandran, 2002, An investigation of the informational role of short interest in the nasdaq market, Journal of Finance, Vol. 57 (5), pp. 2263-2287.

Diamond, D. W., and R. E. Verrecchia, 1987, Constraints on short-selling and asset price 
adjustment to private information, Journal of Financial Economics, Vol. 18 (2), pp. 277-311.

Diether, K. B., K. H. Lee, and I. M. Werner, 2008, Short-sale strategies and return predictability, Review of Financial Studies, Vol. 22 (2), pp. 575-607.

Engelberg, J. E., A. V. Reed, and M. C. Ringgenberg, 2012, How are shorts informed?: Short sellers, news, and information processing, Journal of Financial Economics, Vol. 105 (2), pp. 260-278.

Engelberg, J. E., A. V. Reed, and M. C. Ringgenberg, 2018, Short-selling risk, Journal of Finance, Vol. 73 (2), pp. 755-786.

Engsted, T., T. Q. Pedersen, and C. Tanggaard, 2012, Pitfalls in var based return decompositions: A clarification, Journal of Banking \& Finance, Vol. 36 (5), pp. 1255-1265.

Eom, Y. S., 2012, Short-selling before analyst downgrades, Korean Journal of Financial Studies, Vol. 41 (2), pp. 309-340.

Fama, E. F., and K. R. French, 1992, The cross-section of expected stock returns. Journal of Finance, Vol. 47 (2), 427-465.

Grossman, S. J., and J. E. Stiglitz, 1980, On the impossibility of informationally efficient markets, American Economic Review, Vol. 70 (3), pp. 393-408.

Henry, T. R., and J. L. Koski, 2010, Short selling around seasoned equity offerings, Review of Financial Studies, Vol. 23 (12), pp. 4389-4418.

Hwang, S. W., and Y. S. Cho, 2011, A study on the relationship between stock lending \& borrowing transaction and stock market volatility, Korean Journal of Financial Management, Vol. 28 (1), pp. 11-38.

Karpoff, J. M., and X. Lou, 2010, Short sellers and financial misconduct, Journal of Finance, Vol. 65 (5), pp. 1879-1913.

Kelly, B., and H. Jiang, 2014, Tail risk and asset prices, Review of Financial Studies, Vol. 27 (10), pp. 2841-2871.

Kim, J. O., 2000, An empirical investigation of short sales: Evidence from the Korea stock exchange, Journal of Korean Securities Association, Vol. 26, pp. 343-397.

Kim, J. O., and H. J. Lee, 2013, The short-sales profits of foreign investor, Journal of Knowledge Studies, Vol. 11 (1), pp. 25-49.

Kim, J. S., K. S. Eom, and K. B. Binh, 2011, Foreign investors' short sales and individual stock prices in the Korean stock market, Korean Journal of Financial Management, Vol. 28 (3), pp. 139-187.

Lamont, O. A., and J. C. Stein, 2004, Aggregate short interest and market valuations, American Economic Review, Vol. 94 (2), pp. 29-32.

Ludvigson, S. C., and S. Ng, 2007, The empirical risk-return relation: A factor analysis approach, Journal of Financial Economics, Vol. 83 (1), pp. 171-222. 
Lynch, A., B. Nikolic, X. Yan, and H. Yu, 2014, Aggregate short selling, commonality, and stock market returns, Journal of Financial Markets, Vol. 17 (1), pp. 199-229.

McCracken, M., 2007, Asymptotics for out of sample tests of granger causality, Journal of Econometrics, Vol. 140 (2), pp. 719-752.

McLean, R. D., and J. Pontiff, 2016, Does academic research destroy stock return predictability?, Journal of Finance, Vol. 71 (1), pp. 5-32.

Mele, A., 2007, Asymmetric stock market volatility and the cyclical behavior of expected returns, Journal of Financial Economics, Vol. 86 (2), pp. 446-478.

Miller, E. M., 1977, Risk, uncertainty, and divergence of opinion, Journal of Finance, Vol. 32 (4), pp. 1151-1168.

Neely, C., D. Rapach, J. Tu, and G. Zhou, 2014, Forecasting the equity risk premium: The role of technical indicators, Management Science, Vol. 60 (7), pp. 1772-1791.

Pettenuzzo, D., A. Timmermann, and R. Valkanov, 2014, Forecasting stock returns under economic constraints, Journal of Financial Economics, Vol. 114 (3), pp. 517-553.

Rapach, D., and G. Zhou, 2013, Forecasting stock returns, Handbook of Economic Forecasting, Vol. 2, pp. 328-383.

Rapach, D. E., M. C. Ringgenberg, and G. Zhou, 2016, Short interest and aggregate stock returns, Journal of Financial Economics, Vol. 121 (1), pp. 46-65.

Senchack, A. J., and L. T. Starks, 1993, Short-sale restrictions and market reaction to short-interest announcements, Journal of Financial and Quantitative Analysis, Vol. 28 (2), pp. 177-194.

Seneca, J. J., 1967, Short interest: Bearish or bullish?, Journal of Finance, Vol. 22 (1), pp. 67-70.

Shleifer, A., and R. W. Vishny, 1997, The limits of arbitrage, Journal of Finance, Vol. 52 (1), pp. 35-55.

Song, C. S., 2006, Articles: Motives for short selling from securities lending and stock returns, Journal of Korean Securities Association, Vol. 35 (6), pp. 1-37.

Wang, S. F., and K. H. Lee, 2015, Do foreign short-sellers predict stock returns? Evidence from daily short-selling in Korean stock market, Pacific-Basin Finance Journal, Vol. 32 (1), pp. 56-75.

Welch, I., and A. Goyal, 2007, A comprehensive look at the empirical performance of equity premium prediction, Review of Financial Studies, Vol. 21 (4), pp. 1455-1508.

Woo, M. C., and M. A. Kim, 2017, Motivation of short-selling in KOSPI and KOSDAQ market, Korean Journal of Financial Studies, Vol. 46 (1), pp. 159-186.

Yi, J. S., K. B. Binh, and G. I. Jang, 2010, The causal relationship between stock price and short sales: Evidence from the Korean stock market, Korean Journal of Financial Studies, Vol. 39 (3), pp. 449-489. 